CRIANÇAS PEQUENAS

EM ESCOLAS OU INSTITUIÇÕES PÚBLICAS DE

ENSINO INFANTIL

E A EDUCAÇÃO EM SAÚDE BUCAL

JOSÉ MAURO DE CASTRO FIGLIOLIA

Dissertação apresentada à Faculdade de Odontologia de Bauru, da Universidade de São Paulo, como parte dos requisitos para obtenção do título de Mestre em Odontologia, área de Odontologia em Saúde Coletiva.

Bauru-SP

2004 
CRIANÇAS PEQUENAS

\section{EM ESCOLAS OU INSTITUIÇÕES PÚBLICAS DE \\ ENSINO INFANTIL \\ E A EDUCAÇÃo EM SAÚDE BUCAL}

JOSÉ MAURO DE CASTRO FIGLIOLIA

Dissertação apresentada à Faculdade de Odontologia de Bauru, da Universidade de São Paulo, como parte dos requisitos para obtenção do título de Mestre em Odontologia, área de Odontologia em Saúde Coletiva.

Orientador: Prof. Dr. Arsenio Sales Peres

Bauru-SP

2004 


\section{Figliolia, José Mauro de Castro Figliolia}

F468c Crianças Pequenas em Instituições Públicas de Ensino Infantil

e a Educação em Saúde Bucal / José Mauro de Castro Figliolia.

-Bauru, 2004.

129p: $30 \mathrm{~cm}$

Dissertação (Mestrado) - Faculdade de Odontologia de Bauru.USP

Orientador: Prof. Dr. Arsenio Sales Peres

Autorizo a reprodução total ou parcial, da referida Dissertação de Mestrado.

José Mauro de Castro Figliolia

Autor

Data 


\section{JOSÉ MAURO DE CASTRO FIGLIOLIA}

19 de agosto de 1962

São Paulo - SP

Data e local de nascimento

Filiação

Dilair Figliolia

Melytha Morato Castro Figliolia

$1983-1986$

Curso de Graduação em Odontologia pela Pontifícia Universidade Católica de Campinas - PUCCAMP.

$1998-1999$

Curso de Pós-Graduação (Latu Sensu)Especialização Odontologia em Saúde Coletiva, na Faculdade de Odontologia de Bauru - USP.

$2001-2004$

Curso de Pós-Graduação em Odontologia em Saúde Coletiva, ao nível de Mestrado, na Faculdade de Odontologia de Bauru - USP. 
Desde 1990

Cirurgião-dentista - Prefeitura

Municipal de Bauru - SP

Associações

CROSP - Conselho Regional de

Odontologia do Estado de São Paulo

APCD - Associação Paulista de

Cirurgiões-Dentistas 
A Educação Sanitária, até os anos 60, articulada com ditames da razão, da ciência excluía tudo o que não razão, adormecendo no educador a prática social enquanto sustentáculo da prática sanitária, deixando no tempo uma lacuna possível de recuperação. De acordo com Cardoso de Melo (1993) é preciso recuperar um espaço possível que o próprio sistema de ensino abafou - o espaço da reflexão, da crítica e por que não, dos sonhos (...), onde uma dose acertada de paixão atrelada à razão poderá permitir que as pessoas sintam-se pessoas e não coisas mendigando e implorando direitos sociais subtraídos.

Oliveira, 1997 


\section{AGRADEÇO E DEDICO ESTE TRABALHO}

\section{A DEUS PAI,}

Todo Poderoso, pela minha vida e da minha família;

aos meus pais DILAIR e MELYTHA,

que com muito amor e dedicação nortearam minha formação pessoal;

à minha amada esposa, amiga e companheira, SUZANA LUZIA, pelo incentivo e compreensão, carinho e amor, apoiando e auxiliando-me nos momentos difíceis e ajudando-me a alcançar mais este objetivo;

aos meus filhos queridos PEDRO LUIZ e AMANDA, que mesmo sem entender os vários momentos difíceis e os que estive ausente, souberam me compreender com paciência, carinho e amor; 
aos meus cunhados e cunhadas BENTO e SUZETE, WALTER e SANDRA pelo constante apoio e incentivo, sempre que precisei;

aos meus irmãos ANTONIO MÁRIO e MAURA FERNANDA pelo apoio e incentivo;

às minhas mães afetivas ELY e ANITA minha avó HERONDINA minha sogra THEREZA

sempre prontas a ajudar quando se fez necessário;

Muito Obrigado 


\section{AGRADECIMENTOS ESPECIAIS}

Ao Professor Doutor Arsenio Sales Peres, meu orientador, que com seriedade, experiência e profissionalismo conduziu-me no desenvolvimento deste trabalho.

Ao Prof. Dr. José Roberto de Magalhães Bastos, sempre nos incentivando, estimulando, transmitindo seus conhecimentos e vivência com muita dedicação.

Com muito carinho ao Prof. Dr. Vitoriano Truvijo Bijella, sempre atencioso nos incentivando, estimulando, transmitindo seus conhecimentos e vivência com muita dedicação.

A Profa ${ }^{\text {a }}$ Dra . Sandra Coelho Ávila de Aguiar, que com sabedoria soube me estimular e me ajudar, no desenvolvimento deste trabalho. 


\section{AGRADEÇO AINDA:}

Aos docentes do Departamento de Odontopediatria, Ortodontia e Saúde Coletiva da Faculdade de Odontologia de Bauru - USP, Prof. Dr. José Roberto de Magalhães Bastos, Prof. Dr. Vitoriano Truvijo Bijella, Prof ${ }^{a}$ Dr ${ }^{\underline{a}}$ Nilce Emy Tomita, Prof. Dr. José Roberto Pereira Lauris, Prof. Dr Arsenio Sales Peres, Prof. Dr. Ernesto Pilotto Gomes Medeiros, Prof. Dr. Eymar Sampaio Lopes e Drª . Silvia Helena Carvalho Sales Peres pelos ensinamentos transmitidos.

Aos docentes da Faculdade de Odontologia de Bauru - USP.

Às funcionárias do Departamento de Odontopediatria, Ortodontia e Saúde Coletiva da Faculdade de Odontologia de Bauru - FOB-USP pela amizade e agradáveis momentos de convivência.

Às colegas do curso de Mestrado Flávia, Heloísa, Patrícia, Rosana, Selma e Soraia. 
Às colegas do curso de Doutorado em Patologia Bucal Rosário e Suzana e ainda ao meu filho Pedro pela ajuda iluminada e fundamental à conclusão deste trabalho.

"Como chegar a outro chão, e outros lugares, conhecer novas paisagens, inteirar-se de novos cultivos, se deleitar com outras cores e formas de terra, se espelhar e se moldar, se se recusa a ir??? Para longe ou perto, para próximo ou mui distante, para onde se possa hastear a própria bandeira e dizer: Neste território, eu pisei."

"O medo do Novo" - trecho do livro de Fanny Abramovich"

A todos os funcionários do Serviço de Documentação da Faculdade de Odontologia de Bauru - FOB-USP, pela paciência e orientação que sempre me dedicaram.

Aos funcionários do Serviço de Xerocópia que atuam na Faculdade de Odontologia de Bauru - FOB-USP, por colaborarem sempre eficientes e atenciosos.

A todos os funcionários da Faculdade de Odontologia de Bauru FOB-USP, por colaborarem no anonimato. 


\section{AGRADECIMENTOS INSTITUCIONAIS}

À Faculdade de Odontologia de Bauru - USP, na pessoa de sua Diretora Profa. Dra Maria Fidela de Lima Navarro;

ao Setor de Pós-Graduação da Faculdade de Odontologia de Bauru - USP, presidido pelo Prof. Dr. José Carlos Pereira,

à Prefeitura Municipal de Bauru, na pessoa do Prefeito Nilson Costa, Secretário Municipal de saúde Dr Hanna Georges Saab, Drạa Jaíra Maria Rocco Kirchner, Drª Eliane Fetter Telles Nunes, Dr - Sônia Maria Alessio Alves Fiocchi, Dra - Sueli Ianase, Dra - Vera H. Tavares Lugo, Drª Ana Aida Lins do Valle, Dr $\stackrel{a}{a}$ Elisabeth Rodrigues Pontes, Psicóloga Roseli D'Ávila Vasconcelos, Assistente Social Joziane Lozija Carrapato, Enfa Margareth Biondo e demais funcionários que me possibilitaram a realização deste curso. 


\section{SUMÁRIO}

RESUMO X Xiii

$1 \quad$ INTRODUÇÃO

2 PROPOSIÇÃO

$3 \quad$ METODOLOGIA $\quad 8$

$4 \quad$ ANÁLISE E DISCUSSÃO DOS ACHADOS 10

$\begin{array}{lll}4.1 & \text { Conceitos } & 11\end{array}$

4.2 História da criança 28

4.3 História da infância e da educação infantil 36

4.4 História da educação no Brasil 38

4.5 A educação infantil como direito da criança 45

4.6 Estatuto da criança e do adolescente 47

4.7 Lei de diretrizes e bases 55

4.8 Referencial curricular nacional para educação infantil $\quad 68$

4.9 Referencial curricular nacional para educação infantil - 71

4.10 Orientações didáticas $\quad 75$

4.11 Organização do tempo

4.12 Organização do espaço e seleção dos materiais 76

4.13 Observação, registro e avaliação formativa 76

4.14 Âmbitos e eixos de trabalho $\quad 77$

4.15 Lei no 10.172, nove de janeiro de 2001

4.16 Educação em saúde 89

4.17 Papel profissional dos educadores de saúde 102

$5 \quad$ CONSIDERAÇÕES FINAIS 109

REFERÊNCIAS BIBLIOGRÁFICAS 119

$\begin{array}{lr}\text { ABSTRACT } & 128\end{array}$ 


\section{RESUMO}

O objetivo deste estudo foi identificar, descrever e interpretar aspectos históricos, conceituais e legais, as dificuldades e desafios que se relacionam com a criança pequena e a educação infantil, enfatizando a educação em saúde bucal, nas instituições de ensino infantil. Analisaram-se documentos oficiais e outros que se relacionam com a educação e/ou saúde e que servem ou servirão de suporte às ações de Educação em Saúde Bucal desenvolvidas nas instituições de educação infantil. 0 objetivo primordial foi fornecer suporte teórico para profissionais e estudantes da área de saúde e educação, que participam, desenvolvem ou pretendem participar e/ou desenvolver programas educacionais sobre saúde bucal para crianças de tenra idade. 0 resultado deste estudo afirma que os documentos estudados oferecem importante fonte de pesquisa para alunos e profissionais, da Saúde ou Educação, interessados na educação em saúde, especialmente na educação em saúde bucal voltada às instituições de educação infantil. 0 resultado esperado será altamente positivo se os programas educacionais forem desenvolvidos em conjunto e contando com a integração e envolvimento de membros da comunidade, das universidades e equipes das áreas da saúde e educação, enfatizando a integração das atividades de Educação em Saúde à Educação em Saúde Bucal, em função do desenvolvimento integral da criança e de seu direito legal e moral à Educação e Saúde, garantidos na Constituição Nacional. 
INTRODUÇÃO 


\section{INTRODUÇÃo}

Desde o Brasil colônia já existia a preocupação com a criança.

A criança de zero a seis anos foi objeto de atenção nesses quinhentos anos, sobretudo por inspiração da igreja, no início do processo de colonização, tendo como um de seus protagonistas a figura de Padre Anchieta. Em carta endereçada a Inácio de Loyola, em julho de 1554, o religioso faz menção aos orfanatos mantidos pela Companhia de Jesus, para abrigar órfãos vindos de Portugal ${ }^{31}$.

Dentre os grandes anseios da humanidade, a manutenção ou obtenção de saúde é um dos mais almejados.

Segundo CHAVES ${ }^{14}$, em 1986, a revolução industrial, que começou na Inglaterra no fim do século XVIII, resultou num crescimento rápido das aglomerações urbanas. Nas cidades, porém, as condições de vida favoreciam a propagação de doenças e a mortalidade era maior do que nas zonas rurais. Relatórios hoje famosos, como os de CHADWICK $^{51}$ sobre as condições sanitárias da classe operária na Inglaterra, e de SHATTUCK ${ }^{53}$ sobre a situação em Massachusetts, nos Estados Unidos, despertaram a atenção das autoridades para a necessidade de adoção de certas medidas de caráter coletivo, com relação a abastecimento de água, remoção de dejetos, melhoria das habitações a fim de evitar epidemias de várias doenças que então dizimavam as populações urbanas. Tornou-se óbvia a necessidade de 
uma nova profissão para tomar a si o encargo de tais misteres. Essa profissão, a saúde pública, a princípio recrutou os seus membros entre os médicos e engenheiros, e gradativamente, com a expansão de seu campo de atuação, foi incorporando elementos oriundos de outras profissões.

O mesmo autor relata que a saúde pública evoluiu muito nestes últimos cem anos. 0 impacto da ciência e da tecnologia sobre a sociedade modificou profundamente as condições de vida das populações. 0 coeficiente de mortalidade caiu e o crescimento natural das populações de muitos países efetuou-se em ritmo até então nunca atingido. A melhoria das condições de higiene nas cidades em geral permitiu o aparecimento de aglomerados humanos, as metrópoles modernas, com populações enormes. A saúde pública, concentrada inicialmente no saneamento do meio ambiente e no controle das doenças transmissíveis, expandiu o seu campo de atuação à medida que certos problemas iam sendo satisfatoriamente resolvidos. A fim de entender o problema da mortalidade infantil, garantir a sobrevivência em boas condições de saúde do produto da concepção, salvaguardando ao mesmo tempo a saúde materna, a saúde pública desde cedo incluiu a higiene materno-infantil entre suas atividades. Além desta, a acumulação e codificação de dados sobre as causas de mortalidade e morbidade, o fortalecimento de recursos de laboratório para fins diagnósticos e a educação sanitária do público, foram também incluídos no esquema clássico das atividades de saúde pública. A estas, gradativamente, outras mais foram se incorporando: a higiene dental, a nutrição, a higiene industrial e a higiene mental. 
Como conseqüência da expansão do seu campo de atuação, aumentou consideravelmente o número das profissões envolvidas no trabalho de saúde pública. A noção de trabalho de equipe foi firmemente estabelecida por pura necessidade.

A equipe de saúde pública hoje inclui numerosas profissões e sub-profissões. Uma equipe de saúde pública, hoje em dia, requer a cada momento a competência e colaboração de profissionais das ciências físicas, das ciências biológicas e das ciências sociais, conclui CHAVES ${ }^{14}$.

Para que o indivíduo ou coletividade tenha saúde, é necessário a aquisição e manutenção de hábitos saudáveis, que incluam desde uma alimentação balanceada, atividades físicas, intelectuais e recreativas até hábitos de higiene corporal e bucal; entretanto, esses hábitos só serão adquiridos através do desenvolvimento de trabalhos de educação em saúde que contemplem educação em saúde bucal.

A saúde da população brasileira é muito precária, e infelizmente, a ausência de saúde bucal vem colaborando para isso, assim sendo, são necessários programas de educação em saúde e que nesses esteja incluído, educação em saúde bucal. Esses programas, se aplicados a pré-escolares, podem facilitar a mudança precoce de maus hábitos (vícios) e a aquisição de novos hábitos, conseqüentemente, gengiva, dentição decídua e permanente saudáveis² .

Segundo WALTER et al.57, há um impacto positivo no nível de saúde bucal se a higienização é boa e, especialmente, se a adoção de hábitos adequados inicia-se nos primeiros anos de vida. 
Durante o período que vai, aproximadamente, de dois a três anos e de seis a sete anos, a criança experimenta sempre uma necessidade de movimentos que ela domina e coordena cada vez melhor ${ }^{18}$.

Quando se fala em adoção de hábitos adequados por crianças, deve-se ter em mente em que fase de desenvolvimento se encontra a população infantil alvo, pois para cada fase da criança, há uma característica comportamental, emocional, intelectual e motora específica, que deve ser levada em consideração para a elaboração de programas educacionais voltados para a Educação em Saúde e que nesses esteja inserido à Educação em Saúde Bucal, foco deste estudo. 
PROPOSIÇÃO 


\section{PROPOSIÇÃO}

A proposta do presente estudo é identificar, agrupar, descrever e interpretar alguns aspectos históricos, conceituais e legais, as dificuldades e desafios relacionados com a educação infantil e a educação em saúde, focando a educação em saúde bucal, nas instituições públicas de ensino infantil. Selecionando e analisando documentos oficiais e outros que se relacionam com a educação e/ou saúde infantil. Fornecer suporte teórico à profissionais e estudantes das áreas de Saúde e da Educação que participam, desenvolvem, pretendem desenvolver ou participar de programas educacionais visando a Educação em Saúde Bucal e conseqüentemente, a promoção da saúde de crianças matriculadas em instituições de atenção ao ensino infantil. 
METODOLOGIA 


\section{METODOLOGIA}

Esta investigação se alinha na vertente qualitativa de pesquisa, considerou como fonte de coleta de dados documentos oficiais de reconhecida importância, tese de Livre-Docência, Dissertações de Mestrado, livros e artigos já concluídos e publicados. Esses documentos foram selecionados com base nos critérios de pertinência e relevância.

Neste sentido foram escolhidos aqueles que se relacionam com educação e/ou saúde e que por sua origem servem de suporte às ações que se desenvolvem nas escolas, pois contemplam aspectos gerais de educação, de educação em saúde e de Educação em Saúde Bucal em particular, relacionados à Educação Infantil.

Após a leitura de diversos documentos, o corpus da pesquisa ficou assim constituído:

- Constituição da República Federativa do Brasil, 1988;

- Lei no 9.394/96 - Lei de Diretrizes e Bases da Educação (LDB);

- Lei no 10.172/2001 - Plano Nacional de Educação (PNE);

- Parâmetros Curriculares Nacionais: (PNC);

- Referencial Curricular para a Educação Infantil (RCNEI).

Como forma de tratamento do material escolhido, com base nos propósitos, natureza e objetivos, foi a Análise de Conteúdo. 
Do ponto de vista operacional, a análise se processou em três etapas fundamentais: pré-análise; exploração do material e tratamento dos resultados (inferências e interpretações). 
ANÁLISE E DISCUSSÃO DOS ACHADOS 


\section{ANÁLISE E DISCUSSÃO DOS ACHADOS}

\subsection{CONCEITOS}

\subsubsection{SEGUNDO CHAVES ${ }^{14}$ (1986):}

A definição de saúde dada pela Organização Mundial da Saúde é hoje clássica: "Saúde é um estado de completo bem-estar físico, mental e social e não apenas a ausência de enfermidade". É uma definição que dá um conceito positivo da saúde; considera a saúde como um estado suscetível de gradações. É possível ter mais ou menos saúde, sem estar doente.

Essa definição, que imediatamente ganhou foros de aceitação universal, veio suplantar o conceito anteriormente dominante, negativo, de considerar a "saúde" apenas como ausência de doença. Tal definição por antítese não teria cabimento hoje.

A definição de saúde acima apresentada pode-se considerar ideal e, assim, difícil de ser atingida.

É impossível traçar a faixa de separação entre saúde e doença. Indivíduos medicamente doentes comportam-se e agem muitas vezes como em plena saúde. Enquanto outros, medicamente saudáveis, vivem vidas vazias, ineficientes, enfermiças. A dificuldade em traçar com precisão a linha divisória vem reforçar o conceito positivo de saúde.

Dos três componentes da definição de saúde, os dois primeiros, bem-estar físico e mental, são perfeitamente reconhecidos como sob a 
responsabilidade da medicina moderna, a medicina psicossomática. Já a manutenção do bem-estar social foge da alçada das chamadas profissões de saúde, e exige, para sua obtenção ou manutenção, uma atuação em escala muito mais ampla dos diversos órgãos da sociedade organizada.

E o bem-estar social inclui, além das atividades no campo da saúde, atividades no campo da nutrição, educação, vivenda, recreação, proteção ao consumidor, proteção contra o desemprego, seguridade social, entre outros. 0 bem-estar social é objeto de programas completos de governo, e não de qualquer de suas unidades.

\section{Saúde Bucal}

Para CHAVES ${ }^{14}$, o conceito de saúde bucal é uma abstração útil. A rigor, saúde é um estado do indivíduo, que não pode subsistir como saúdes parciais dos diversos órgãos e sistemas. No entanto, para efeitos práticos, o conceito de saúde parcial, saúde bucal em nosso caso, serve para identificar objetivos parciais em programas de saúde, desde que não se perca de vista a limitação deste conceito.

A saúde bucal, como estado de harmonia, normalidade ou higidez da boca, só tem significado quando acompanhada, em grau razoável, de saúde geral do indivíduo.

\section{Odontologia}

À medida que a arte de curar se foi desvencilhando de seu conteúdo de misticismo, magia e poderes sobrenaturais, e que a doença deixou de ser considerada entidade misteriosa e sim a resultante de 
causas naturais e, como tal, suscetível de prevenção e tratamento, a profissão médica se foi estabelecendo em bases cada vez mais sólidas.

A quantidade de conhecimentos que se foram acumulando de geração em geração e a diversificação progressiva dos métodos de tratamento das enfermidades, tornando praticamente impossível o domínio, por um só homem, das práticas necessárias à conservação da saúde, redundou no aparecimento de um número cada vez maior de subdivisões da profissão médica.

Já em fins do século XVIII, com Fauchard, ficou bem caracterizada e estruturada uma profissão independente, a odontologia, especializada no sentido da manutenção da saúde e recuperação funcional do aparelho mastigatório.

Continuando com o raciocínio de CHAVES ${ }^{14}$, sem pretender entrar aqui na história das profissões da saúde, convém ressaltar um aspecto saliente observado em sua evolução: a especialização profissional e a gênese de profissões auxiliares. Tanto uma como outra são conseqüências lógicas do progresso técnico e científico de cada profissão.

\section{Medicina Preventiva}

À medida que a medicina se foi assenhoreando de dados mais completos sobre a etiopatogenia das doenças e afecções, foi-lhe também sendo possível idealizar e testar métodos de impedir sua ocorrência ou atenuar-lhes o curso. A medicina preventiva passou a ser a denominação usada, em oposição à medicina curativa, para o conjunto de conhecimentos e métodos que visam à prevenção das doenças. 0 
aparecimento da microbiologia como ciência básica médica e as descobertas no fim do século passado (século XIX) e no início deste (século $\mathrm{XX}$ ) no setor da imunologia, tiveram significado especial no progresso da medicina preventiva.

\section{Odontologia Preventiva e Odontologia Curativa}

O autor relata que também em odontologia tem sido costume usar as expressões odontologia preventiva e odontologia curativa, assistencial ou reparadora, para caracterizar os dois aspectos da prática profissional. Como a medicina, teve a odontologia em sua gênese orientação predominantemente curativa e reparadora. Ainda hoje a orientação tradicional do ensino profissional é no sentido curativo. Só a pouco, e pouco idéias e princípios básicos de odontologia preventiva vão sendo incorporados e recebendo ênfase nos cursos de formação profissional. Apesar do progresso dos últimos anos, podemos dizer que a situação atual ainda é de grande predomínio da atitude curativa no ensino profissional, tanto médico como odontológico.

\section{A dicotomia da medicina e da odontologia}

A dicotomia da medicina e da odontologia, em uma fase preventiva e uma fase curativa tem sido em geral associada na prática a um conceito também dicotomizado do exercício profissional. A medicina e a odontologia preventivas seriam atribuições da saúde pública. A parte curativa das duas profissões seria atribuição da clínica particular e dos serviços sociais. Apesar da fragilidade dos argumentos 
a favor da dualidade de atribuições entre clínica particular, serviços sociais e a saúde pública, há que reconhecer que ela constitui ainda a maneira de pensar de um número significante de médicos e dentistas.

\section{Existem duas medicinas e duas odontologias, uma preventiva, e uma curativa?}

CHAVES $^{14}$ responde: Obviamente não. Existe uma só medicina e uma só odontologia: a melhor que pode ser praticada num momento dado da evolução da doença. Prevenção e tratamento formam um todo contínuo. 0 tratamento oportuno e eficiente é uma forma de prevenir complicações e seqüelas.

\section{Prevenção}

A prevenção, em sentido amplo, inclui a prevenção sensu strictu e o tratamento; é sinônimo de "boa medicina" e "boa odontologia". 0 conceito amplo de prevenção, enunciado por LEAVELL E CLARK ${ }^{37}$, é eminentemente didático, sintético, integrativo e é o único compatível com uma prática profissional de um padrão elevado, seja em clínica particular, seja em um serviço público.

\section{Saúde Pública}

Se fossemos definir saúde pública, pelo que ela faz num instante dado, deveríamos ter um país específico em mente, pois no dia de hoje, em mais da metade do mundo, a saúde pública luta com problemas que 
já cessaram de existir em grande número de países. Além disso, cada país tem sua própria cultura, sua maneira de dividir as responsabilidades entre o indivíduo e a sociedade, que implicam definições de quais sejam as atividades da saúde pública.

Numa definição hoje clássica, Winslow considera a saúde pública a "ciência e a arte de prevenir a doença, prolongar a vida e promover a saúde e a eficiência física e mental mediante esforços organizados da comunidade para o saneamento do meio, o controle das doenças transmissíveis, a educação dos indivíduos sobre higiene pessoal, a organização dos serviços médicos e de enfermagem para o tratamento preventivo e diagnóstico precoce das enfermidades, o desenvolvimento de um mecanismo social que assegure a cada indivíduo um nível de vida adequado à conservação da saúde, organizando estes benefícios de tal modo que cada cidadão se encontre em condições de gozar de seu direito natural à saúde e longevidade".

Em um certo ponto, a definição restringe a organização dos serviços médicos e de enfermagem ao tratamento preventivo das enfermidades. Essa restrição é apenas aparente se admitirmos o conceito amplo de prevenção esposado por LEAVELL E CLARK ${ }^{37}$, segundo o qual, em qualquer parte em que se oponha uma barreira à marcha da enfermidade, visando até mesmo limitar a incapacidade ou reabilitar o indivíduo, se estará sempre prevenindo um mal maior. Vista desta forma, a prevenção equivale ao melhor tratamento que se pode fazer num instante dado da evolução da doença. É óbvio que quanto mais precoce a atuação como regra, melhores as responsabilidades de sucesso, constituindo o ideal evitar a ocorrência da doença. 
McGAVRAM $^{39}$ propôs uma definição prática de saúde pública: é o diagnóstico científico e o tratamento dos problemas de saúde das comunidades como entidades. Esta definição simples poderá servir universalmente a qualquer país. Segundo ela, o paciente do sanitarista é a comunidade: assim como o médico ou o dentista trata o paciente individual, o sanitarista trata o paciente coletivo, a comunidade, a coletividade ou o corpo político.

A diferença entre um dentista ou médico que exercem a clínica particular e os que se dedicam à saúde pública é basicamente uma diferença de atitude, de ponto de vista. A clínica particular preocupa-se com um número limitado de indivíduos considerados os clientes de determinado profissional, que demandam ativamente seus serviços.

CHAVES $^{14}$ segue argumentando que: no caso do sanitarista, a situação é diferente: seu paciente é a comunidade, sua responsabilidade é a saúde coletiva. Ora, esta nada mais é que a soma das saúdes individuais de cada membro da comunidade. Por causa disto o sanitarista, como o clínico particular, esta também virtualmente interessado na saúde de cada indivíduo. Porém, ao passo que o clínico esta primariamente interessado na saúde dos que o procuram, o sanitarista está igualmente interessado em todos os indivíduos, talvez mais ainda nos que não procuram serviços de saúde.

Ao definir simplesmente saúde pública como saúde do povo, KNUTSON ${ }^{36}$ considera-a como a saúde coletiva de um grupo, de uma comunidade, de uma nação. Faz uma magnífica comparação entre a atividade do dentista clínico e do sanitarista, mostrando como até certo ponto o trabalho de saúde pública reproduz em nível diferente as etapas clássicas do trabalho clínico. 
Assim, ao exame de um paciente, corresponde o inquérito ou levantamento da situação em uma comunidade. Ao processo de diagnóstico dos males que afligem um paciente corresponde a análise dos dados obtidos num inquérito. 0 planejamento de um tratamento em si equivale à execução do programa. 0 pagamento de honorários em saúde pública chama-se financiamento do programa e a avaliação dos resultados do tratamento é semelhante à avaliação dos programas de saúde pública.

\section{Odontologia Social}

Não é difícil definir odontologia social tomando como base à definição de saúde pública proposta por McGAVRAN39. A odontologia social é a disciplina de saúde pública responsável pelo diagnóstico e tratamento dos problemas de saúde bucal da comunidade.

\section{Níveis de Prevenção}

Segundo LEAVELL E CLARK ${ }^{37}$ a palavra prevenção em medicina e odontologia não deve ser tomada no sentido restrito de prevenção pura, prevenção da ocorrência das enfermidades.

Cada doença tem sua maneira própria de evoluir, quando abandonada ao próprio curso, constitutiva do que se chama a história natural da doença em questão.

Nossa interferência na marcha de qualquer doença pode ser considerada como a interposição de barreiras em distintas etapas de seu ciclo evolutivo. As etapas em que podemos atuar, em que podemos 
colocar nosso obstáculo à progressão da doença, denominamos de "níveis de prevenção", são as seguintes:

\section{1o. Promoção da Saúde}

Neste nível procuramos criar as condições mais favoráveis para que um indivíduo esteja em condições de resistir ao ataque de uma doença ou grupo de doenças. Neste nível nossa atuação é inespecífica. Procuramos aumentar a resistência do indivíduo e coloca-lo em um ambiente favorável à saúde. Medidas como nutrição adequada, exercícios ao ar livre, vivenda confortável e limpa, roupa adequada ao clima, trabalho estimulante sob o ponto de vista mental, recreação, vida familiar, não constituem método específico de prevenção de doenças, mas ajudam a tornar o ambiente desfavorável à maioria das doenças.

\section{2‥ Proteção Específica}

Neste nível já estamos, como o nome indica, protegendo o indivíduo especificamente contra uma dada doença. Lidamos agora com métodos positivos de eficiência mensurável, comprovada. Estão neste grupo medidas como vacinação, iodização do sal, fluoração da água.

\section{3ํ. Diagnóstico precoce e tratamento imediato}

Para as doenças que não foram evitadas seja porque não existem métodos para atuação em nível anterior, seja porque os métodos 
existentes não foram aplicados, nossa atuação deverá orientar-se no sentido de identificá-las e tratá-las o mais cedo possível. No câncer oral, por exemplo, o diagnóstico precoce e o tratamento imediato constituem a melhor forma à disposição no momento para enfrentar o problema.

\section{4ํ. Limitação do Dano}

Quando falhamos na aplicação de medidas em níveis anteriores, devemos, em qualquer fase em que se encontre a doença, procurar limitar o dano, evitar um mal maior. Assim, ao fazer um capeamento de uma polpa acidentalmente exposta, estamos evitando um mal maior, uma infecção periapical; ao extrair um dente portador de uma infecção periapical crônica, estamos evitando um mal maior: uma repercussão a distância, em órgão importante, da infecção localizada no ápice dentário (infecção focal). Resumindo: nossas intervenções comuns em odontologia curativa e restauradora tem finalidade preventiva, quando se encara prevenção em sentido mais amplo.

\section{5o. Reabilitação}

Chegamos agora ao último nível de prevenção. Em certas doenças, estamos ainda desprovidos de armas, de métodos, para atuação em níveis anteriores. Já nos defrontamos com o fato consumado. A doença evolui, até sua fase final, à nossa revelia, e nos defrontamos com o indivíduo lesado pela doença, portador de suas seqüelas, incapacitado total ou parcialmente. Ainda aqui ocorre um trabalho de prevenção: prevenção de que o indivíduo se torne uma carga permanente para si 
próprio, para sua família e para a sociedade. Esta forma de prevenção, de 5o. E último nível, é a que se denomina reabilitação.

\section{Uma visão sintética e algumas generalizações sobre Níveis de Prevenção, segundo CHAVES14:}

1. A prevenção, em sentido amplo, abrange a nossa atuação em qualquer fase da evolução da doença. A odontologia preventiva, também em sentido amplo, é sinônimo de odontologia integral, ou seja, a melhor odontologia que pode ser praticada num instante dado.

2. Em sentido restrito, a odontologia preventiva é praticada no período de pré-patogênese (prevenção primária) e a odontologia curativa ou restauradora a que é praticada no período de evolução das doenças dentárias, ou pós ele (prevenção secundária ou terciária).

3. O ideal da odontologia é a prevenção, o mais cedo possível, na história natural de cada doença. A atuação em nível mais alto só deveria ser justificada por inexistência de recursos em níveis anteriores, ou por ter-se esgotado sua capacidade protetora.

4. $\quad$ ideal da odontologia social e da saúde pública é a prevenção primária; na impossibilidade desta, far-se-á a prevenção secundária e terciária. 


\section{Níveis de Aplicação}

Em várias doenças, como a cárie dentária, dispomos de vários métodos em um mesmo nível de prevenção.

Que diferenças são importantes, do ponto de vista da saúde pública, para selecionar métodos situados em um mesmo nível?

Esse problema é particularmente importante quando se trata de escolher métodos preventivos de 2 o nível (proteção específica).

\section{Nível: Ação Governamental Ampla}

Uma série de problemas de saúde pública, como o de certas deficiências nutricionais, o da tuberculose, do tracoma, exigem, para obtenção de resultados apreciáveis, programas governamentais de envergadura, capazes de melhorar o nível de vida das populações.A melhoria do estado de nutrição de um povo, de maneira global, tipifica um método de saúde pública, destinado à promoção da saúde (1ํo nível de prevenção) e que exige uma ação político-social muito complexa, constitutiva de um verdadeiro programa de governo. Não se trata de programas que possam desenvolver por um ou dois ministérios. Exigem uma ação coordenada de todas as unidades governamentais no sentido do desenvolvimento sócio-econômico. 


\section{2‥ Nível: Ação Governamental Restrita}

Certos métodos de saúde pública, como, por exemplo, a iodação do sal, a fluoretação da água, a vacinação antivariólica em massa, exigem uma ação de governo mais restrita que a anterior, envolvendo apenas uma ou duas unidades governamentais, um ou dois ministérios. Assim, um programa de fluoração da água depende principalmente da ação combinada de dois ministérios: o da Saúde e o do Interior. Sem ser fácil é, contudo, muito mais simples que um programa destinado a melhorar a nutrição em certas áreas pobres e super lotadas.

\section{3‥ Nível: Paciente - Profissional}

A maioria dos métodos do $3^{\circ}$, 4ํㅡ e 5ํo níveis de prevenção exige, para ser posta em prática, uma ação bilateral envolvendo o paciente e um profissional de nível universitário superior. A categoria do profissional exigido introduz um fator econômico na prestação dos serviços, vinculado ao seu custo.

\section{4ํ. Nível: Paciente - Auxiliar ou Subprofissional}

Este nível constitui uma simplificação do anterior. Os métodos deste nível também pressupõem uma relação bilateral do paciente com uma segunda pessoa, porém de nível educacional inferior ao universitário.

Toda vez que um método de saúde pública pode ser colocado em prática por pessoal auxiliar, sob a supervisão de profissionais, suas 
possibilidades de aplicação em larga escala se multiplicam e seus custos per capita se reduzem.

\section{5o. Nível: Ação Individual}

Aplicação de número grande de métodos preventivos depende quase exclusivamente de decisões na esfera individual sobre a prática de atos favoráveis à saúde. Aparentemente seria um nível cômodo, prático, de aplicação dos métodos, pois envolve um único indivíduo, e o principal interessado em sua própria saúde. No entanto, sabemos como é difícil motivar indivíduos a modificar hábitos, alterar formas tradicionais de vida, que tem raízes às vezes profundas na própria cultura. Por essa razão, métodos deste nível, exigindo basicamente trabalho de educação sanitária, são dos mais difíceis de aplicar. Como exemplo, poderíamos citar a introdução ou modificação de hábitos de higiene bucal. Mesmo em clientela selecionada, como geralmente é a do periodontista, a criação de um hábito como a massagem gengival constitui às vezes barreira quase intransponível.

Creio que não é necessário insistir sobre esse ponto. 0 5ํㅡ́vel, o nível individual de aplicação dos métodos é dos mais difíceis.

Em resumo, os métodos de saúde pública podem ser classificados, do ponto de vista da ação necessária à sua aplicação, em cinco níveis CHAVES $^{14}$. Os dois primeiros exigem uma ação impessoal, coletiva, política, de natureza ampla (1ํo nível) ou restrita (2º nível). Os dois seguintes exigem uma prestação de serviço, seja por pessoal profissional (3ํㅡível) ou auxiliar (4º nível). 0 último depende de uma ação individual (5onível). 
Um mesmo método pode ser transplantado de um nível para outro, sempre no sentido da procura de níveis mais favoráveis à aplicação coletiva. Uma boa parte da arte da odontologia social constituirá em como adaptar métodos do $3^{\circ}$ nível ao 4oㅡ nível, para possibilitar sua aplicação a grandes grupos de população, e em como obter métodos preventivos de aplicação universal em $2^{\text {o }}$ nível.

\subsubsection{SEGUNDO CANDEIAS ${ }^{9}$ (1997):}

\section{Educação em saúde}

Entende-se por quaisquer combinações de experiências de aprendizagem delineadas com vistas a facilitar ações voluntárias conducentes à saúde.

A palavra combinação enfatiza a importância de combinar múltiplos determinantes do comportamento humano com múltiplas experiências de aprendizagem e de intervenções educativas.

A palavra delineada distingue o processo de educação de saúde de quaisquer outros processos que contenham experiências acidentais de aprendizagem, apresentando-o como uma atividade sistematicamente planejada.

Facilitar significa predispor, possibilitar e reforçar.

Voluntariedade significa sem coerção e com plena compreensão e aceitação dos objetivos educativos implícitos e explícitos nas ações desenvolvidas e recomendadas. 
Ação diz respeito a medidas comportamentais adotadas por uma pessoa, grupo ou comunidade para alcançar um efeito intencional sobre a própria saúde.

Define-se Promoção em Saúde como uma combinação de apoios educacionais e ambientais que visam a atingir ações e condições de vida conducentes à saúde.

Combinação refere-se à necessidade de mesclar os múltiplos determinantes da saúde (fatores genéticos, ambiente, serviços de saúde e estilo de vida) com múltiplas intervenções ou fontes de apoio.

Educacional refere-se à educação em saúde tal como acima definida.

Ambiental refere-se a circunstâncias sociais, políticas, econômicas, organizacionais e reguladoras, relacionadas ao comportamento humano, assim como a todas as políticas de ação mais diretamente relacionadas à saúde. Utiliza-se aqui para fazer referência àquelas forças da dinâmica social, que incidem sobre uma situação específica e que vão muito além do estudo do ambiente físico ou dos serviços médicos destinados à população. Dizem respeito àqueles fatores ambientais que também precisam ser considerados no planejamento de atividades de promoção em saúde.

Note-se que essa se diferencia dos outros dois maiores componentes da saúde pública por fixar a engenharia do meio ambiente à proteção em saúde e a administração no ambiente médico aos serviços de prevenção para a saúde. 
A expressão condições de vida permite que a definição de promoção em saúde ultrapasse os limites daqueles fatores estritamente comportamentais, observáveis em geral durante 0 relacionamento interpessoal que ocorre no âmbito do nível local, para prender-se a uma teia de interações muito mais complexa, constituída pela cultura, por normas e pelo ambiente socioeconômico, cada um deles se associando com o significado histórico mais amplo do que se convencionou denominar de estilo de vida. 


\subsection{HISTÓRIA DA CRIANÇA}

KLATCHOIAN ${ }^{35}$, em 2002, analisando a literatura histórica, sociológica e educacional, observa que a situação da criança no núcleo familiar e na própria sociedade nunca foi privilegiada e que a história nos mostra que até o século XIX a infância foi considerada um período de transição rapidamente superado e sem importância, um período desprezível da vida do ser humano.

Relata ainda que, Philipe Ariés (1986), em seu livro História Social da Criança e da Família, propôs a teoria de que a sociedade tradicional confundia as crianças e os jovens com os adultos, ignorando o conceito de infância e juventude. A criança era, portanto, diferente do adulto, mas apenas no tamanho e na força enquanto as outras características permaneciam iguais. Pode-se dizer que a criança era comparada ao anão, que ocupava um lugar importante na tipologia medieval. Naquela época, as pessoas viviam misturadas umas às outras, senhores e criados, crianças e adultos, em casas permanentemente abertas às indiscrições dos visitantes. A densidade social não deixava lugar para a família. Não que ela não existisse, mas que ela não existia como um sentimento ou como valor.

A sociedade tradicional medieval via mal a criança e pior ainda o adolescente. A duração da infância era reduzida ao período mais frágil enquanto o 'filhote de homem' não podia cuidar de si mesmo sozinho. Tão logo a criança apresentasse algum desembaraço físico, era misturada em meio aos adultos e partilhava de seus trabalhos e jogos. De 'criancinha pequena' ela se transformava imediatamente em 'homem jovem', sem passar pelas etapas da juventude. 
A autora prossegue:

No século XVII, os filhos de família continuavam a desempenhar funções domésticas que os aproximavam do mundo dos serviçais. Logo a transmissão de valores e dos conhecimentos e a socialização das crianças não eram controladas pela família. A criança era logo afastada de seus pais e, durante séculos, a educação foi garantida pela aprendizagem de ofícios. A passagem da criança pela família e pela sociedade era muito breve e muito insignificante, (...) a criança muito pequenina, demasiada frágil ainda para se misturar à vida dos adultos, 'não contava'.

"Perdi dois ou três filhos pequenos, não sem tristeza, mas sem desespero", reconhece Montaigne. A "paparicação" era reservada à criancinha em seus primeiros anos de vida enquanto ela ainda era uma "coisinha" engraçadinha. As pessoas se divertiam com as crianças pequenas como animalzinho de estimação. Se ela morresse então, como muitas vezes acontecia, alguns poderiam ficar desolados, mas a regra geral era não fazer muito caso, pois uma outra criança logo a substituiria. Quando ela conseguia superar os primeiros perigos e sobreviver ao tempo da "paparicação", era comum que passasse a viver em outra casa que não a sua família.

Em sua pesquisa KLATCHOIAN ${ }^{35}$ constata que a família não tinha função afetiva, sua missão principal era: a conservação dos bens, a prática comum de um ofício, a ajuda mútua, entre homem e mulher; pois isolados não podiam sobreviver, ainda em caso de crise a proteção da honra e da vida. A afetividade entre os cônjuges, os pais e os filhos, não era necessária à existência nem ao equilíbrio da família, porém se existisse, tanto melhor. 
A partir do século XVII, a escola substitui a aprendizagem como meio de educação. Isso quer dizer que a criança deixou de ser misturada aos adultos e de aprender a vida diretamente no contato com eles. A criança foi separada do adulto e mantida a distância numa espécie de quarentena, antes de ser solta no mundo. A escola foi a responsável por esse período de afastamento da criança de sua família.

NUNES ${ }^{42}$, em 1981, ressalta que o século XVII foi à época da gênese da ciência moderna, com grandes avanços no campo das matemáticas e com o emprego vitorioso do método experimental que deu impulso às ciências da natureza, e à física de maneira especial. Na matemática, distinguiram-se Claude Mydorge com seu Tratado sobre as Cônicas (1631-1635), Gerard Desargues com seus estudos de geometria projetiva, o italiano Bonaventura Cavalieri, que preparou as bases do cálculo infinitesimal, com Geometria Indivisibilium Continuorum (1635). Blaise Pascal escreveu aos 16 anos o Ensaio sobre as Cônicas e três anos depois inventou a primeira máquina de calcular. Descartes, no seu pequeno tratado de umas cem páginas, Geometria (1637), expôs os princípios da geometria analítica. Introduziu o uso dos expoentes, explicou as raízes negativas e descobriu a análise. Newton e Leibniz inventaram o cálculo infinitesimal. Acrescenta-se a esse rol as descobertas das leis de Kepler, da mecânica de Galileu, do sistema circulatório de Harvey, da geologia de Stenon, da astronomia de Newton, dos 'animálculos' de Leeuwenhoek, com o microscópio.

Dando seqüência a análise de KLATCHOIAN35:

Começou então um longo processo de enclausuramento das crianças (como dos loucos, dos pobres e das prostitutas). Essa separação das crianças era fruto de um grande movimento de moralização dos 
homens promovido pelos reformadores católicos ou protestantes ligados à igreja, às leis ou ao estado. Mas ela não teria sido realmente possível sem a cumplicidade sentimental das famílias. A família tornouse o lugar de uma afeição necessária entre os cônjuges e entre pais e filhos, algo que ela não era antes. Essa afeição se exprimiu, sobretudo com (a) importância adquirida pela educação. Não se tratava mais de criar os filhos em função dos bens e da honra. Tratava-se de um sentimento inteiramente novo. Os pais passaram a se interessar pelos estudos de seus filhos.

A família começou então a se organizar em torno da criança e a lhe dar uma tal importância (...) tornou-se impossível perdê-la ou substituíla. Houve, portanto uma redução voluntária da natalidade, observável no século XVIII.

Philipe Áries, segundo KLATCHOIAN35, nos chama a atenção para um fenômeno muito importante e que começa a ser mais conhecido: a persistência até o fim do século XVII do infanticídio tolerado. Não se trata de uma prática aceita, o infanticídio era um crime severamente punido. No entanto, era praticado em segredo, camuflado sob forma de um acidente. As crianças morriam asfixiadas naturalmente na cama dos pais, onde dormiam. Os bispos proibiam com uma veemência que as crianças fossem postas para dormir na cama dos pais, onde muitas vezes morriam asfixiadas. Quando isso ocorria, o fato não era considerado uma vergonha.

No século XVII, de um infanticídio secretamente admitido, passouse a um respeito cada vez mais exigente pela vida da criança.

No entanto, nos séculos XVIII e XIX persistiu um sentimento de irritação frente à infância. Havia uma reação contra a importância que a 
criança havia adquirido dentro da família e dentro do sentimento da família. Lembremos que os adultos de todas as condições sociais gostavam de brincar com as crianças pequenas. Esse hábito era sem dúvida antigo, mas num determinado momento passou a ser notado a ponto de provocar irritação. Assim, nasceu esse sentimento de irritação diante da infantilidade, que é o reverso moderno do sentimento da infância. Somava-se a este fato o desprezo que essa sociedade sentia pelo professor, o mestre, numa época em que os colégios se tornavam mais numerosos e mais freqüentados, e em que a infância já começava a lembrar aos adultos seu tempo de escola. 0 sentido da inocência infantil resultou, portanto, numa dupla atitude moral com relação à infância: preservá-la da sujeira da vida e especialmente da sexualidade tolerada entre os adultos e fortalecê-la, desenvolvendo o caráter e a razão.

Essa volta da criança ao lar foi um grande acontecimento: deu à família do século XVII sua principal característica, que a distinguiu das famílias medievais. A criança tornou-se um elemento indispensável da vida cotidiana, e os adultos passaram a se preocupar com a sua educação, carreira e futuro. Essa família do século XVII, entretanto, não era a família moderna: distinguia-se desta pela enorme massa de sociabilidade que conservava.

Vimos que na Idade Média a educação das crianças era garantida pela aprendizagem junto aos adultos e que, a partir dos sete anos, as crianças viviam com uma outra família que não a sua. Dessa época em diante, ao contrário, a educação passou a ser fornecida cada vez mais pela escola. A escola deixou de ser reservada aos clérigos para se tornar o instrumento normal da iniciação social, da passagem do estado de infância ao do adulto. 
Do século XVII para frente, a educação passou a ser cada vez mais fornecida pela escola, que se tornou o instrumento normal da iniciação social da passagem da infância ao adulto, sendo então necessário um maior rigor moral dos educadores. Essa evolução correspondeu a uma necessidade nova de rigor moral da parte dos educadores, a uma preocupação de isolar a juventude do mundo sujo dos adultos para mantê-la na inocência primitiva. Mas ela correspondeu também a uma preocupação dos pais em vigiar seus filhos mais perto, em ficar mais perto deles e de não abandona-los mais, mesmo temporariamente, aos cuidados de uma outra família.

KLATCHOIAN 35 , salienta que:

O clima sentimental era agora completamente diferente, mais próximo do nosso, como se a família moderna tivesse nascido ao mesmo tempo em que a escola ou, ao menos, que o hábito geral era educar as crianças na escola.

Nossa civilização moderna de base escolar foi então definitivamente estabelecida. 0 tempo a consolidaria, prolongando e estendendo a escolaridade. Os meios ricos, nobres e burgueses continuaram a entregar suas crianças a amas-de-leite até o fim do século XIX, ou seja, até o momento que em que os progressos de higiene e da assepsia permitiram utilizar sem riscos o leite animal. Contudo, uma mudança significativa ocorreu nesse meio tempo: a ama passou a se deslocar, em lugar da criança, passou a morar na casa da família, e a família passou a recusar a separar-se dos bebês. No século XIX, ninguém ousaria então a consolar-se da perda de uma criança, co esperança de ter outra, como ainda se confessava no século passado. 
Toda a evolução de nossos costumes contemporâneos torna-se incompreensível se desprezarmos esse prodigioso crescimento do sentimento da família. Não foi o individualismo que triunfou, foi a família.

No final no final do século XIX e início do século XX, FREUD ${ }^{22}$, médico vienense, afirma que traumas causadores das perturbações são de natureza sexual, e que existe uma sexualidade na infância, sob forma de impulsos mais ou menos reprimidos na infância, do paciente. FREUD ${ }^{22}$ escreve a célebre frase no prefácio da $4^{\underline{a}}$ edição de seu livro:

“... se a humanidade fosse capaz de instruir-se pela observação direta das crianças, eu poderia ter economizado a fadiga de escrever este livro".

Dessa forma, acontece uma grande virada no pensamento científico e filosófico que vigorava no passado. Freud enfatizou a importância da infância, afirmando que muitas das neuroses tinham origem em traumas ocorridos na infância. A partir de 1920, a Psicanálise começa a desenvolver-se no plano internacional. Forma-se em Viena, uma nova geração de discípulos psicanalistas: William Reich, Karl G. Jung, K. Abraham, Melanie Klein, Alfred Adler.

De meados do século XX para cá, pesquisadores como Winnicott entre outros começam a enfatizar a infância como uma fase especial com necessidades especiais em que se presta atenção ao bebê desde seu nascimento e criam-se conhecimentos de uma psicologia especializada na infância. Há apenas três ou quatro décadas as mulheres de classe média ainda não haviam entrado no mercado de trabalho; a autora conclui: hoje os casais têm em média dois filhos e há uma preocupação exagerada nas famílias de classe média em que a criança tenha uma 
agenda cheia, com aulas de inglês, natação, computação, judô, balé, etc. A criança vive uma rotina cansativa, tendo por outro lado um contacto restringido com os pais, porque o tempo disponível é menor. Por outro lado, os pais ficaram psicologicamente mais sensíveis às necessidades das crianças, a ponto de procurarem compensar a ausência ofertando aos pequeninos presentes, videogames, brinquedos, roupas e até mesmo doces. Na década de setenta, surgiu o conceito da "qualidade do tempo" segundo o qual o importante não era passar horas e horas com os filhos - e sim aproveitar bem o tempo que os pais passam com eles. Mas o que constatamos é que nos dias de hoje o ambiente doméstico tornou-se palco de uma batalha contra o relógio, no qual os pais sentemse obrigados a dar total atenção aos filhos no pouco tempo que dispõem. Isso transformá-se em um esforço extenuante que deixa os pais exaustos e muitas vezes carregando um sentimento de culpa. Muitos pais não deveriam recriminar-se, pois se têm, bons substitutos, pessoas muito ligadas a seus filhos que lhe dêem carinho e atenção, eles podem ficar tranqüilos. Pode ser a avó, a babá, a funcionária da creche ou a professora da escola. 


\subsection{HISTÓRIA DA INFÂNCIA E DA EDUCAÇÃO INFANTIL}

Estudos feitos por KISHIMOT0 ${ }^{31}$, em 1988, sobre a educação infantil nos da um panorama sobre a criança, a educação infantil desde a época do início da colonização no Brasil.

No período colonial, ocorreu o predomínio da assistência social à infância, de caráter filantrópico, religioso, médico e higiênico, sendo oferecida em múltiplos asilos infantis para pobres, doentes, órfãos e abandonados.

No final do século XIX, surgem as creches, com finalidade de atender, mães trabalhadoras (decorrente da urbanização e da industrialização) e mantidas pela igreja, filantropia, empresas e órgãos de assistência social; casas de infância, para atender crianças pobres, mantidas por organizações filantrópicas.

Já no início do século XX, surgem as escolas maternais, para atender filhos de operários, os jardins de infância, para educar crianças de três a seis anos, mantidos por Departamentos ou Secretarias de Educação.Segundo KISHIMOTO30, em 2001, a educação infantil passou por um longo período de marginalização, o que permitiu uma variedade e diversidade de instituições, estruturas de funcionamento e profissionais geralmente com baixa escolaridade.

\subsubsection{OS JARDINS DE INFÂNCIA}

A educação infantil destinada a crianças de quatro a seis anos surge, inicialmente, com os jardins de infância, criados por FROEBEL ${ }^{23}$, oficialmente em 1840, cuja proposta era educar por meio da pedagogia dos jogos. 
FROEBEL ${ }^{23}$ delineou a metodologia dos dons (materiais como bola, cubo, varetas, anéis etc.) e ocupações (atividades sob a orientação da jardineira com o uso dos dons), dos brinquedos (atividades imitativas livres) e jogos (atividades livres com o emprego dos dons).

RIZZO52, em 1985, seguindo a orientação de FROEBEL ${ }^{23}$, o professor pré-escolar deve ser aquele que cuida e "cultiva" as crianças como flores de um jardim, para fazê-las desabrochar em personalidades plenas, para levá-las a atingir o máximo de plenitude e beleza, a que o crescimento total pode levar.

KISHIMOTO ${ }^{30}$, em 2001 relata que os jardins de infância, criados oficialmente na Alemanha, em 1840, acabaram sendo banidos devido a uma política educacional autoritária que julgou inadequado essa instituição infantil, ao valorizar a autonomia infantil em uma Alemanha totalitária. Discípulos dirigiram-se para os Estados Unidos da América do Norte e outros países, expandindo a filosofia dos jardins de infância froebelianos.

Os jardins frobelianos instalados no século XIX, nos Estados Unidos, evidenciam o uso dos dons e ocupações e a marginalização do simbolismo infantil, conforme críticos como Harris e Blow. Harris, ao comentar que "o Kindergarten, ao usar os dons e ocupações, não utiliza o que há de melhor nas invenções de FROEBEL ${ }^{23}$, contido na obra Mutter und Kose-Lieder (Canções da Mãe)". FROEBEL23, em 1912, ressalta o papel das brincadeiras livres que representam o poder da criança de conquistar a natureza. Harris, à semelhança de FROEBEL ${ }^{23}$, já percebera que o jogo tem dois modos de uso: auto-expressão, espontaneidade e meio de ensino: busca de algum resultado. Os muitos erros das jardineiras parecem derivar da falta de compreensão do significado da 
atividade criativa e também, provavelmente da idéia froebeliana de união dos contrários. A harmonia entre direção e liberdade, entre indivíduo e coletividade, parece não ter ocorrido na prática pedagógica, prevalecendo apenas à direção e a autoridade do professor, nas atividades com dons e ocupações, não há como proporcionar a exploração livre dos materiais oferecidos.

\subsection{HISTÓRIA DA EDUCAÇÃO NO BRASIL}

A autora ${ }^{30}$ relata ainda que a história dos jardins de infância começa no Brasil, em 1875, quando Joaquim Menezes Vieira e sua esposa, D. Carlota instalam um jardim de infância para atender crianças de cinco a sete anos. Justificada como necessária para estimular a metodologia intuitiva, considerada apropriada para a escola primária e ao desenvolvimento da inteligência. Naquela época, poucos conheciam os objetivos das instituições infantis e a maioria confundia jardins de infância e asilos infantis.

Por ocasião da reforma do ensino primário e secundário, realizada por Leôncio de Carvalho, no município da Corte, durante a tramitação do projeto em que se introduzia o jardim de infância para crianças de três a sete anos, o senador Junqueira faz a seguinte crítica: 'Kindergarten. É alemão, protestante, o nome católico de asilos ou salas de infância, deve ser banido pela escola liberal. Mas meu fim é demonstrar que isto não tem nada a ver com a instrução primária: é uma instituição de caridade para meninos desvalidos, que serve para que mãe ou pai, sendo nimiamente pobres, quando vão para o seu trabalho, entreguem seus filhos àqueles asilos, como já se faz entre nós e até na 
Bahia, em algumas casas dirigidas pelas irmãs de caridade. Mas aqui era preciso dar esse nome pomposo - jardim de infância'.

Alberto Brandão argumenta ser o jardim de infância uma instituição de caridade, típica da Europa, destinada a prestar auxílio à mãe que trabalha, sem utilidade para o Brasil, onde à mulher cabe apenas a função de cuidar dos filhos e, ainda, atribui a essa instituição o poder de prejudicar a unidade familiar ao tirar a criança muito cedo do lar.

Olympio da Costa considera, indistintamente, jardins de infância ou salas de asilo imitações inconscientes de países industrializados e, como tais, 'objetos de luxo' para um país onde a mulher só concorre como 'fator de produção de filhos e não de renda'. Outras críticas formuladas naquela ocasião desnudam as disputas entre grupos leigos e religiosos. Para os últimos, o jardim de infância seria responsável pelo início precoce na escola, ao introduzir a criança, desde os três anos, e não aos sete, na escola, como propunha a lei. Questionava-se o uso pedagógico do brinquedo, por tirar a espontaneidade do jogo infantil. Tais críticas eram rebatidas pelo grupo favorável à instalação do jardim de infância, com argumentos como o de que o jardim froebeliano não pretendia antecipar a escolaridade e que os partidários do 'ensino fradesco' eram os inimigos dos 'brinquedos infantis', ao pretender introduzir 'ao aprendizado monótono das rezas'.

Segundo KISHIMOTO ${ }^{30}$, no fim do império, o generalizado descaso com a instituição pública justificava em certo sentido, a recusa à instalação do jardim de infância no fim do império. Se o governo, naquela época, não conseguia nem disseminar a escola primária, muito menos se poderia pensar na criação e expansão de jardins de infância. 
Nem mesmo, a entrada da República, com uma nova política favorável a educação consegue modificar tal situação. Alguns acham que a função do Estado não é 'desmamar crianças' e gastar dinheiro e esforço com 'diversões pedagógicas'. Esse modo de pensar corporifica-se nas críticas do renomado educador Kopke. Em aquarela reproduzida pelo jornal $O$ Estado de S. Paulo, associa o jardim de infância a uma instituição assistencial que tem como finalidade única 'desmamar bebê'. Nas representações sociais dos personagens da época, a criança pequena não demandava uma institucionalização, uma vez que deveria ser educada pela mãe, no próprio lar.

Criar instituições para educá-la significava o desperdício de recursos financeiros, uma vez que essa tarefa era das mães. Com a chegada dos protestantes a São Paulo, instala-se o jardim de infância, trazendo a orientação americana como uso de dons e ocupações. Considerada 'educação ante-escolar', a instituição infantil fora adotada na Escola Americana para igualar o sistema de ensino ao país de origem.

Francisco Rangel Pestana, propagandista da República, fundador do jornal $O$ Estado de São Paulo, é escolhido para elaborar a proposta educativa do partido republicano. Ao propor a reforma, Rangel Pestana entende ser a educação um instrumento de mudança social, e a escola, a alavanca do progresso, dela partindo o gérmen das reformas políticas e sociais. Acreditando na possibilidade de mudar o país por meio da formação dos educadores, Rangel Pestana elabora o projeto de reforma da Escola Normal, consubstanciado no decreto no 27 de 12 de março de 1890, que cria as escolas-modelo.

A finalidade básica das escolas-modelo ou classes primárias anexas à Escola Normal é o aperfeiçoamento docente por meio do 
estágio de normalistas e, com isso desenvolver um padrão de ensino para nortear as escolas oficiais. Nesse projeto já se encontra, em sua base, o Kindergarten, para crianças, de quatro a seis anos, fundamentado nas diretrizes de Pestalozzi e Froebel. Entretanto, o jardim de infância oficial só se torna realidade por Gabriel Prestes, Bernardino de Campos e Alfredo Pujol, os quais fornecem a legalidade ao primeiro jardim de infância oficial por meio do decreto $\mathrm{n}^{\circ} 342$, de dois de março de 1896, que, em seu parágrafo único, declara: 'Fica criado um jardim da infância junto a Escola Normal da Capital, como preparo á Escola Modelo; revogadas as disposições em contrário'.

KISHIMOTO ${ }^{30}$, ressalta que mais uma vez a função do jardim de infância é a de preparar os alunos para a escola primária, que funcionava como modelo para suas congêneres e espaço para a prática de estágio. Embora outras motivações sejam responsáveis pelo surgimento do jardim de infância anexo à Escola Normal da praça, Caetano de Campos destaca seu caráter preparatório para a escolaridade subseqüente.

As atividades desenvolvidas nessa unidade reproduzidas pela Revista do Jardim de Infância, de 1897-1898, evidenciam uma farta programação com uso dos dons e ocupações, bastante similar à experiência americana.

Mendes Vieira, um dos mais entusiásticos defensores da proposta froebeliana já criticava algumas práticas durante a Exposição Pedagógica de 1883. Vieira percebe a inadequação de certas atividades sugeridas por FROEBEL ${ }^{23}$, principalmente pelo abuso de abstrações científicas para crianças ainda em fase intuitiva, a rigidez de certos exercícios, o excesso do vocabulário geométrico, o predomínio do espírito científico e o desmensurado apuro nos trabalhos manuais. 
Passadas algumas décadas de funcionamento do jardim de infância instalado na Caetano de Campos, a metodologia froebeliana ali desenvolvida parece não satisfazer certos críticos da educação como Macedo Soares, que aponta a filiação ao modelo americano, como 'servil cópia', responsável pela existência de escolas sem conteúdo, escolas que ostentam uma grandiosidade apenas na aparência, 'escolas de fachada'.

Nessa época, os Estados Unidos, sob a influência do ideário progressivista de DEWEY ${ }^{19}$, estimula alterações nos jogos froebelianos. Blocos de construção, de grandes dimensões, surgem para estimular a motricidade mais ampla em conjunto com o simbolismo infantil e, áreas tematizadas, para brincadeiras simbólicas começam a fazer parte do trabalho infantil.

No Brasil, a reflexão sobre a ação, o saber-fazer deweyano estimula Alice Meirelles Reis a iniciar uma fase de renovação pedagógica no jardim de infância anexo à Escola Normal (Caetano de Campos), provocando alterações qualitativas em seu trabalho. Entre as práticas pedagógicas fotografadas pela professora (acervo da Faculdade de Educação da Universidade de São Paulo) destacam-se áreas de faz de conta, materiais de construção de grandes dimensões, brincadeiras motoras com água e com animais, a elaboração de projetos na forma de centros de interesse, entre outros.

DEWEY ${ }^{19}$, preocupado com o preparo da criança para enfrentar problemas da vida, traz a experiência social para o interior da escola, criando espaço para o jogo. A inclusão da experiência vivenciada fora da escola, na família e comunidade, por meio do jogo simbólico, possibilita a integração dos personagens e temas da vida social no cotidiano infantil. Com DEWEY19, alteram-se os objetivos da educação infantil: de 
escola preparatória à escola primária torna-se preparatória à vida social. É a socialização da criança, a meta prioritária da educação infantil, por tais razões o jogo ocupa uma parcela importante nessa proposta.

Outra concepção de DEWEY $^{19}$ muito presente na prática pedagógica da professora Reis é o uso do learning by doing. 0 aprender fazendo, nada mais é que a prática reflexiva durante o processo de realização da atividade. Para dar conta dessas inovações a professora Reis, reivindica dois itens: uma sala para ser ocupada apenas por seus alunos e a diminuição dos alunos de quarenta para trinta, o que permite a organização do espaço físico, o uso independente dos brinquedos e materiais e a continuidade de projetos desenvolvidas pelos alunos nos dias subseqüentes. A experiência da professora Reis, pouco efeito teve na expansão de estabelecimentos de educação infantil e na forma de condução do trabalho infantil. A expansão de pré-escolas anexas a grupos escolares que se inicia nos anos de 1930 acabou aproximandose cada vez mais ao modelo do ensino fundamental.

Segundo KISHIMOTO ${ }^{30}$, a transformação dos Parques Infantis em Escolas de Educação infantil ocorre nos anos de 1970, concomitante ao surgimento, nas esferas administrativas do ensino federal, estadual e municipal, de organismos responsáveis pela educação infantil.

Agrupamentos etários, distintos para crianças de quatro a seis anos, estruturam as novas instituições infantis dos anos de 1970, com propostas relacionadas à psicologia cognitiva, especialmente piagetiana. Embora essa teoria também privilegiasse os jogos infantis, há cada vez maior ênfase em processos de escolarização voltados para a 
escrita e o cálculo, pela ausência de uma prática reflexiva que alterasse o contexto vigente.

Pesquisas efetuadas em pré-escolas demonstram que a prática pedagógica continua referendando materiais gráficos e jogos educativos ${ }^{12,32,33,46}$.

Uma pesquisa efetuada nas Escolas Municipais de Educação Infantil, em 1997-1998, demonstra que brinquedos e brincadeiras são ainda utilizados para promover predominantemente processos de escolarização.

A pesquisa identificou pouca presença de brinquedos de natureza simbólica como bonecas, carrinhos, apetrechos domésticos, entre outros destinados ao faz-de-conta; jogos de construção, tão valorizados desde a criação dos jardins de infância e jogos destinados à socialização da criança. Predominam jogos educativos, à semelhança dos dons e ocupações froebelianos; materiais destinados à motricidade fina e à atividade gráfica e brinquedos e materiais que valorizam a motricidade e educação física.

É bom lembrar que a professora Reis, nos anos de 1920 a 1940 reorganizou o tamanho da turma e a disposição da sala para realizar suas inovações.

Segundo KISHIMOTO ${ }^{30}$, cabe lembrar também, que as normas definidas pelo MEC, em 1998, sobre agrupamentos infantis estabelecem o número máximo de 25 crianças para a faixa etária de quatro e cinco anos. Hoje (2001), certas escolas acolhem quarenta crianças por sala.

\subsection{A EDUCAÇÃO INFANTIL COMO DIREITO DA CRIANÇA}


De acordo com KISHIMOTO ${ }^{30}$ a legislação que trata da infância, notadamente as Constituições Federais requerem um longo percurso para definir o Direito da Criança à Educação Infantil.

Até o século XIX foi omissa, apresentando, em seguida, a figura do Amparo e da Assistência ou cuidados como eixos para analisar a vida infantil.

A omissão da lei evidencia-se no comentário do Anuário de 1918, que se refere à legislação do ensino particular que não especifica nenhuma forma de controle sobre os asilos infantis e creches, entendendo que tais organizações propiciam apenas atividades voltadas a trabalhos de agulhas: "Não estão sujeitas a inspecção e fiscalização as casas onde se ensina somente a coser, bordar e outras obras de agulha" 31 .

CURY17, em 1988, analisa as Constituições Federais demonstrando a infância percorrendo o caminho da assistência ao direito à educação infantil: a Constituição de 1891 é omissa, nada menciona sobre a infância; a de 1946 utiliza o termo Amparo e Assistência e a de 1937 remete para cuidados especiais.

A preocupação com uma lei própria para discutir a Assistência e o Amparo só surge com a Constituição Federal de 1967 e a Junta Militar de 1969. A Lei de Diretrizes e Bases no 4.024 de 1961, timidamente insere a Educação Infantil dentro do Grau Primário e a Lei 5.692/71 mantém a mesma situação resgatando a necessidade de a empresa organizar creches para filhos de mães que trabalham.

A inovação surge com a Constituição de $1988^{3}$, que muda substancialmente as especificações sobre a infância. Não se trata de dar Assistência ou Amparo como era prática corrente nas instituições 
infantis, que ao proteger a criança, a mulher, o trabalhador "assistiam e guardavam" seus filhos, gerando concepções como "depósitos infantis", "creche como mal necessário", mas garantir o direito à educação. Ao inaugurar um Direito, impôs o Dever, especialmente ao Município. Inicia o processo de valorização da educação infantil, garantindo o direito da criança à educação infantil e o dever do estado de manter esse direito ${ }^{30}$.

A Constituição ${ }^{3}$ de 1988 inicia o processo de valorização da educação infantil ao inseri-la no ensino básico, garantindo o direito da criança à educação infantil e o dever do estado de manter esse direito. Dentro desse quadro, interessa averiguar o caminho percorrido pela educação infantil para atender as especificações legais como o direito da criança à educação, a integração de creches e pré-escolas em centros de educação infantil destinado às crianças de zero a seis anos, com vistas a integrar o cuidar e educar, evidenciando o brincar e a socialização como paradigmas para desenvolver e educar a criança.

A Constituição de 1988³, afirma; “O dever do Estado com a educação será efetivado mediante garantia de: (...) atendimento em creche e pré-escola às crianças de zero a seis anos de idade" (Constituição de 1988, inciso IV do artigo 208).

\subsection{ESTATUTO DA CRIANÇA E DO ADOLESCENTE}

Lei no 8.069, de 13 de julho de 1990, destaca também, o direito da criança a esse atendimento.

Estaremos neste momento, tecendo alguns comentários e fazendo alguns questionamentos, procurando levar o leitor a uma análise mais 
reflexiva com referência à Lei no 8.069, de 13 de julho de 1990, que enfoca a criança, e que dispõe sobre o Estatuto da Criança e do Adolescente ${ }^{41}$ e dá outras providências.

\section{Das disposições preliminares.}

Art. 1o. Esta Lei dispõe sobre a proteção integral à criança e ao adolescente.

Este Artigo enfoca que a Lei estabelece a proteção integral.

Art. 2º . Considera-se criança, para efeitos desta Lei, a pessoa até doze anos de idade incompletos, e adolescente aquela entre doze e dezoito anos de idade.

- Já este, define a faixa etária que se situa a criança, ou seja, perante a Lei se é considerado criança até os 12 anos de idade.

Art. 3‥ A criança e o adolescente gozam de todos os direitos fundamentais inerentes à pessoa humana, sem prejuízo da proteção integral de que trata esta Lei, assegurando-se-lhes, por lei ou por outros meios, todas as oportunidades e facilidades, a fim de lhes facultar 0 desenvolvimento físico, mental, moral, espiritual e social, em condições de liberdade e de dignidade.

- Aqui, temos os "direitos" sendo "assegurados" por esta Lei ou podendo ser usado "outros meios", "assegurando todas as 
oportunidades e facilidades", com a finalidade de proporcionar / permitir o desenvolvimento físico, mental (...).

Art.4ํ. É dever da família, da comunidade, da sociedade em geral e do poder público assegurar, com absoluta prioridade, a efetivação dos direitos referentes à vida, à saúde, à alimentação, à educação, ao esporte, ao lazer, à profissionalização, à cultura, à dignidade, ao respeito, à liberdade e à convivência familiar e comunitária.

- Notamos aqui, que a Lei estabelece como um "dever" da família, da comunidade e da sociedade em geral, ou seja, é dever de todos, "a efetivação" ou seja, de produzir um efeito real, permanente, fixo.

Parágrafo único. A garantia de prioridade compreende:

a) primazia de receber proteção e socorro em quaisquer circunstâncias;

b) precedência de atendimento nos serviços públicos ou de relevância pública;

c) preferência na formulação e na execução das políticas sociais públicas;

d) destinação privilegiada de recursos públicos nas áreas relacionadas com a proteção à infância e à juventude.

Art.5‥ Nenhuma criança ou adolescente será objeto de qualquer forma de negligência, discriminação, exploração, violência, crueldade e opressão, punido na forma da lei qualquer atentado, por ação ou omissão, aos seus direitos fundamentais. 
- Imaginemos: Várias crianças pequenas, uma escola de ensino infantil e a falta de um programa de Educação em Saúde ou com um programa de Educação em Saúde, sem incluir à Educação em Saúde Bucal.

Art.6º. Na interpretação desta Lei levar-se-ão em conta os fins sociais a que ela se dirige, as exigências do bem comum, os direitos e deveres individuais e coletivos, e a condição peculiar da criança e do adolescente como pessoas em desenvolvimento.

- Sem necessidade de tecer qualquer comentário.

\section{Título II}

\section{Dos Direitos Fundamentais}

\section{Capítulo I}

\section{Do Direito à Vida e à Saúde.}

Art.7ํ. A criança e o adolescente tem direito a proteção à vida e à saúde, mediante a efetivação de políticas sociais públicas que permitam o nascimento e desenvolvimento sadio e harmonioso, em condições dignas de existência.

- Imaginemos novamente: Uma instituição infantil, sem um programa de Educação em Saúde Bucal.

Art. 13‥ Os casos de suspeita ou confirmação de maus-tratos contra criança ou adolescente serão obrigatoriamente comunicados ao 
Conselho Tutelar da respectiva localidade, sem prejuízo de outras providências legais.

- Como podemos definir serviços públicos de saúde e de educação, não desenvolverem programas e políticas de Educação em Saúde.

Art.14º. 0 Sistema Único de Saúde promoverá programas de assistência médica e odontológica para a prevenção das enfermidades que ordinariamente afetam a população infantil, e campanhas de educação sanitária para pais, educadores e alunos.

- Apenas uma pergunta: 0 que é a cárie dentária?

\section{Capítulo II}

\section{Do Direito à Liberdade, Respeito e à Dignidade}

Art. 15. A criança e o adolescente tem direito à liberdade, ao respeito e à dignidade como pessoas humanas em processo de desenvolvimento $\mathrm{e}$ como sujeitos de direitos civis, humanos e sociais garantidos na constituição e nas leis.

- Como podemos definir um programa de educação em saúde bucal em uma instituição pública de ensino infantil?

Art. 16. 0 direito à liberdade compreende os seguintes aspectos:

Inciso IV - brincar, praticar esportes e divertir-se;

Inciso V - participar da vida familiar e comunitária, sem discriminação; 
- Como é visto uma criança pequena com a dentição destruída?

Art. 17. 0 direito ao respeito consiste na inviolabilidade da integridade física, psíquica e moral da criança e do adolescente, abrangendo a preservação da imagem, da identidade, da autonomia, dos valores, idéias e crenças, dos espaços e objetos pessoais.

- O que fazer no serviço público quando uma criança pequena necessita tratamento endodôntico (de canal) ou uma extração?

Art. 18. É dever de todos velar pela dignidade da criança e do adolescente, pondo-os a salvo de qualquer tratamento desumano, violento, aterrorizante, vexatório ou constrangedor.

- Agora imagine você, seu filho ou irmão, sendo essa criança.

\section{Capítulo IV}

\section{Do Direito à Educação, à Cultura, ao Esporte e ao Lazer}

Art. 53. A criança e o adolescente têm direito à educação, visando ao pleno desenvolvimento de sua pessoa, preparo para o exercício da cidadania e qualificação para o trabalho, assegurando-se-lhes:

\section{II- direito de ser respeitado por seus educadores}


- O que o "dentista" faz numa escola ou instituição de ensino infantil ?

- Educação em Saúde bucal atrapalha as atividades pedagógicas da escola / creche.

Parágrafo único. É direito dos pais ou responsáveis ter ciência do processo pedagógico, bem como participar da definição das propostas educacionais.

- Os pais têm pressa, e já temos muitas reuniões com eles, tem mesmo que agendar uma reunião com o "dentista"?

Art. 54. É dever do estado assegurar à criança e ao adolescente:

IV - atendimento em creche e pré-escola às crianças de zero a seis anos de idade;

Art. 58. No processo educacional respeitar-se-ão os valores culturais, artísticos e históricos próprios do contexto social da criança e do adolescente, garantindo-se a estes a liberdade da criação e o acesso às fontes de cultura.

- Que tal um teatrinho de fantoches com um tema voltado para saúde e saúde bucal? 


\section{Título III}

\section{Da Prevenção}

\section{Capítulo I}

\section{Disposições Gerais}

Art. 70. É dever de todos prevenir a ocorrência de ameaça ou violação dos direitos da criança e do adolescente.

- Como os serviços públicos atendem às necessidades odontológicas das crianças pequenas de zero a seis anos de idade?

Art. 71. A criança e o adolescente têm direito a informação, cultura, lazer, esportes, diversões, espetáculos e produtos e serviços que respeitem sua condição peculiar de pessoa em desenvolvimento.

- Como você avalia a falta da Educação em Saúde Bucal do processo pedagógico de uma instituição de ensino infantil?

Art. 73. A inobservância das normas de prevenção importará em responsabilidade da pessoa física ou jurídica, nos termos desta Lei.

\section{Título III}

\section{Das Medidas de Proteção}

\section{Capítulo I}




\section{Disposições Gerais}

Art. 98. As medidas de proteção à criança e ao adolescente são aplicáveis sempre que os direitos reconhecidos nessa Lei forem ameaçados ou violados:

I - por ação ou omissão da sociedade ou do Estado;

II - por falta, omissão ou abuso dos pais ou responsável;

- Como definir a situação de uma criança pequena que freqüenta uma instituição pública de ensino infantil, com a saúde bucal comprometida?

\section{Capítulo II}

\section{Das Medidas Específicas de Proteção}

Art. 100. Na aplicação das medidas levar-se-ão em conta as necessidades pedagógicas, preferindo-se aquelas que visem ao fortalecimento dos vínculos familiares e comunitários.

Art. 101. Verificada qualquer das hipóteses previstas no art. 98, a autoridade competente poderá determinar, dentre outras, as seguintes medidas...

\subsection{LEI DE DIRETRIZES E BASES}


Lei $\mathrm{n}^{0}$ 9.394, de 20 de dezembro de 1996, estabelece as Diretrizes e Bases da educação nacional.

\section{TÍTULO II}

\section{Dos Princípios e Fins da Educação Nacional}

Art. 2o. A educação, dever da família e do Estado, inspirada nos princípios de liberdade e nos ideais de solidariedade humana, tem por finalidade o pleno desenvolvimento do educando, seu preparo para o exercício da cidadania e sua qualificação para o trabalho.

- O educando tem garantia Legal do direito à educação e ao pleno desenvolvimento, e concomitante a família e o estado o dever de atender essa determinação da Lei.

\section{TÍTULO III}

Do Direito à Educação e do Dever de Educar

IV - atendimento gratuito em creches e pré-escolas às crianças de zero a seis anos de idade;

\section{TíTULO IV}

\section{Da Organização da Educação Nacional}

Art. 8‥ A União, os Estados, o Distrito Federal e os Municípios organizarão, em regime de colaboração, os respectivos sistemas de ensino. 
Parágrafo 1ํ. Caberá à União a coordenação da política nacional de educação, articulando os diferentes níveis e sistemas e exercendo função normativa, redistributiva e supletiva em relação às demais instâncias educacionais.

Parágrafo $2 \stackrel{0}{ }$. Os sistemas de ensino terão liberdade de organização nos termos desta Lei.

- A Lei inspirada nos princípios de liberdade e nos ideais de

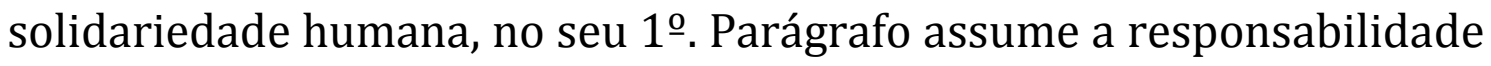
de coordenar à política nacional de educação, articulando (juntando, unindo) os diferentes níveis e sistemas embora tendo função normativa, no seu parágrafo $2^{\circ}$. Estabelece que os sistemas de ensino terão liberdade de organização.

Art. 9o. A União incumbir-se-á de:

I - elaborar o Plano Nacional de Educação, em colaboração com os Estados, o Distrito Federal e os Municípios;

IV - estabelecer, em colaboração com os Estados, o Distrito Federal e os Municípios, competências e diretrizes para a educação infantil, o ensino fundamental e o ensino médio, que nortearão os currículos e seus conteúdos mínimos, de modo a assegurar formação básica comum;

- Cria, instrui, organiza em colaboração entre as diferentes esferas governamentais, competências e diretrizes, que irão orientar, guiar os currículos e seus conteúdos mínimos. É aqui que se criam mecanismos para se respaldar e apoiar a Educação em Saúde bucal. 
Art. 11. Os Municípios incumbir-se-ão de:

I - organizar, manter e desenvolver os órgãos e instituições oficiais dos seus sistemas de ensino, integrando-os às políticas e planos educacionais da União e dos Estados;

II - exercer ação re-distributiva em relação às suas escolas;

III - baixar normas complementares para o seu sistema de ensino;

IV - autorizar, credenciar e supervisionar os estabelecimentos do seu sistema de ensino;

V - oferecer a educação infantil em creches e pré-escolas, e, com prioridade, o ensino fundamental, permitida a atuação em outros níveis de ensino somente quando estiverem atendidas plenamente as necessidades de sua área de competência e com recursos acima dos percentuais mínimos vinculados pela Constituição Federal à manutenção e desenvolvimento do ensino.

Parágrafo único. Os Municípios poderão optar, ainda, por se integrar ao sistema estadual de ensino ou compor com ele um sistema único de educação básica.

- A Lei garante o oferecimento da educação infantil, torna-a um direito do pequeno cidadão. E incube o município de integrado às políticas e planos educacionais da união e estado, tendo liberdade e competência para organizar e desenvolver órgãos e instituições oficiais do seu sistema de ensino (princípios de descentralização).

Art. 12. Os estabelecimentos de ensino, respeitadas as normas comuns e as do seu sistema de ensino, terão a incumbência de: 
I - elaborar e executar sua proposta pedagógica;

II - administrar seu pessoal e seus recursos materiais e financeiros;

III - assegurar o cumprimento dos dias letivos e horas-aula estabelecidas;

IV - velar pelo cumprimento do plano de trabalho de cada docente;

V - prover meios para a recuperação dos alunos de menor rendimento;

VI - articular-se com as famílias e a comunidade, criando processos de integração da sociedade com a escola;

VII - informar os pais e responsáveis sobre a freqüência e o rendimento dos alunos, bem como sobre a execução de sua proposta pedagógica.

- Proposta pedagógica

Art. 13. Os docentes incumbir-se-ão de:

I - participar da elaboração da proposta pedagógica do estabelecimento de ensino;

II - elaborar e cumprir plano de trabalho, segundo a proposta pedagógica do estabelecimento de ensino;

III - zelar pela aprendizagem dos alunos;

IV - estabelecer estratégias de recuperação para os alunos de menor rendimento;

V - ministrar os dias letivos e horas-aula estabelecidas, além de participar integralmente dos períodos dedicados ao planejamento, à avaliação e ao desenvolvimento profissional;

VI - colaborar com as atividades de articulação da escola com as famílias e a comunidade. 
Art. 14. Os sistemas de ensino definirão as normas da gestão democrática do ensino público na educação básica, de acordo com as suas peculiaridades e conforme os seguintes princípios:

I - participação dos profissionais da educação na elaboração do projeto pedagógico da escola;

II - participação das comunidades escolar e local em conselhos escolares ou equivalentes.

Art. 15. Os sistemas de ensino assegurarão às unidades escolares públicas de educação básica que os integram progressivos graus de autonomia pedagógica e administrativa e de gestão financeira, observadas as normas gerais de direito financeiro público.

- Autonomia pedagógica e administrativa, participação da comunidade escolar e local... (Art. 14. parágrafo II).

Art. 18. Os sistemas municipais de ensino compreendem:

I - as instituições do ensino fundamental, médio e de educação infantil mantidas pelo Poder Público municipal;

II - as instituições de educação infantil criadas e mantidas pela iniciativa privada;

III - os órgãos municipais de educação.

\section{TíTULO V}

Dos Níveis e das Modalidades de Educação e Ensino 


\section{CAPÍTULO I}

\section{Da Composição dos Níveis Escolares}

Art. 21. A educação escolar compõe-se de:

I - educação básica, formada pela educação infantil, ensino fundamental e ensino médio;

II - educação superior.

- Educação Básica: é aqui que está inserida a Educação Infantil, a grande conquista, já não é mais um Jardim de Infância, agora está integrada a Educação escolar.

\section{CAPÍTULO II}

\section{Da Educação Básica}

\section{Seção I}

\section{Das Disposições Gerais}

Art. 22. A educação básica tem por finalidades desenvolver o educando, assegurar-lhe a formação comum indispensável para o exercício da cidadania e fornecer-lhe meios para progredir no trabalho e em estudos posteriores.

- Finalidade de desenvolver o educando, assegurar-lhe a formação comum indispensável para o exercício da cidadania, será que não se encaixa aqui a Educação em Saúde? Será que saúde bucal tem algo a ver com exercício da cidadania? 
Art. 23. A educação básica poderá organizar-se em séries anuais, períodos semestrais, ciclos, alternância regular de períodos de estudos, grupos não-seriados, com base na idade, na competência e em outros critérios, ou por forma diversa de organização, sempre que o interesse do processo de aprendizagem assim o recomendar.

Parágrafo 1‥ A escola poderá re-classificar os alunos, inclusive quando se tratar de transferências entre estabelecimentos situados no País e no exterior, tendo como base às normas curriculares gerais.

Parágrafo 2. 0 calendário escolar deverá adequar-se às peculiaridades locais, inclusive climáticas e econômicas, a critério do respectivo sistema de ensino, sem com isso reduzir o número de horas letivas previsto nesta Lei.

\section{Seção II}

\section{Da Educação Infantil}

Art. 29. A educação infantil, primeira etapa da educação básica, tem como finalidade o desenvolvimento integral da criança até seis anos de idade, em seus aspectos físicos, psicológico, intelectual e social, complementando a ação da família e da comunidade.

- Aqui neste artigo, não nos deixa dúvidas da conquista das crianças com a inclusão na educação básica e indo mais além ser considerada a primeira etapa desta, ou seja, a primeira etapa de um processo de educação.

Art. 30. A educação infantil será oferecida em: 
I - creches, ou entidades equivalentes, para crianças de até três anos de idade;

II - pré-escolas, para as crianças de quatro a seis anos de idade.

Art. 31. Na educação infantil a avaliação far-se-á mediante acompanhamento e registro do seu desenvolvimento, sem o objetivo de promoção, mesmo para o acesso ao ensino fundamental.

- Será que ter saúde faz parte do desenvolvimento?

\section{TÍTULO VI}

Dos Profissionais da Educação

Art. 61. A formação de profissionais da educação, de modo a atender aos objetivos dos diferentes níveis e modalidades de ensino e às características de cada fase do desenvolvimento do educando, terá como fundamentos:

I - a associação entre teorias e práticas, inclusive mediante a capacitação em serviço;

II - aproveitamento da formação e experiências anteriores em instituições de ensino e outras atividades.

- Será que a saúde bucal não participa do desenvolvimento do educando, no nosso enfoque a criança pequena?

Art. 62. A formação de docentes para atuar na educação básica far-se-á em nível superior, em curso de licenciatura, de graduação plena, em 
universidades e institutos superiores de educação, admitida, como formação mínima para o exercício do magistério na educação infantil e nas quatro primeiras séries do ensino fundamental, a oferecida em nível médio, na modalidade Normal.

- Considerando ser a primeira etapa da educação básica, ou seja, da educação do pequeno cidadão, essa formação admitida satisfaz às necessidades do pequeno cidadão?

Art. 63. Os institutos superiores de educação manterão:

I - cursos formadores de profissionais para a educação básica, inclusive o curso normal superior, destinado à formação de docentes para a educação infantil e para as primeiras séries do ensino fundamental;

II - programas de formação pedagógica para portadores de diplomas de educação superior que queiram se dedicar à educação básica;

III - programas de educação continuada para os profissionais de educação dos diversos níveis.

- Os professores deste país possuem igualdade de oferta e acesso a programas de educação continuada?

Art. 64. A formação de profissionais de educação para administração, planejamento, inspeção, supervisão e orientação educacional para a educação básica, será feita em cursos de graduação em pedagogia ou em nível de pós-graduação, a critério da instituição de ensino, garantida, nesta formação, a base comum nacional. 
Art. 65. A formação docente, exceto para a educação superior, incluirá prática de ensino de, no mínimo, trezentas horas.

Art. 67. Os sistemas de ensino promoverão a valorização dos profissionais da educação, assegurando-lhes, inclusive nos termos dos estatutos e dos planos de carreira do magistério público:

I - ingresso exclusivamente por concurso público de provas e títulos;

II - aperfeiçoamento profissional continuado, inclusive com licenciamento periódico remunerado para esse fim;

III - piso salarial profissional;

IV - progressão funcional baseada na titulação ou habilitação, e na avaliação do desempenho;

V - período reservado a estudos, planejamento e avaliação, incluído na carga de trabalho;

VI - condições adequadas de trabalho.

Parágrafo único. A experiência docente é pré-requisito para o exercício profissional de quaisquer outras funções de magistério, nos termos das normas de cada sistema de ensino.

- Pelo menos na Lei estão assegurados.

Art. 69. A União aplicará, anualmente, nunca menos de dezoito, e os Estados, o Distrito Federal e os Municípios, vinte e cinco por cento, ou o que consta nas respectivas Constituições ou Leis Orgânicas, da receita resultante de impostos, compreendidas as transferências constitucionais, na manutenção e desenvolvimento do ensino público. 
IV - programas suplementares de alimentação, assistência médicoodontológica, farmacêutica e psicológica, e outras formas de assistência social;

V - obras de infra-estrutura, ainda que realizadas para beneficiar direta ou indiretamente a rede escolar;

VI - pessoal docente e demais trabalhadores da educação, quando em desvio de função ou em atividade alheia à manutenção e desenvolvimento do ensino.

- A lei garante receita para programas de assistência médicoodontológica entre outros.

\section{TÍTULO IX}

\section{Das Disposições Transitórias}

Art. 87. É instituída a Década da Educação, a iniciar-se um ano a partir da publicação desta Lei.

Parágrafo 1‥ A União, no prazo de um ano a partir da publicação desta Lei, encaminhará, ao Congresso Nacional, o Plano Nacional de Educação, com diretrizes e metas para os dez anos seguintes, em sintonia com a Declaração Mundial sobre Educação para Todos.

Parágrafo 4‥ Até o fim da Década da Educação somente serão admitidos professores habilitados em nível superior ou formados por treinamento em serviço. 
- A preocupação fica com o receio de se "formar" professores a "toque de caixa" e devido às diferenças existentes num país da dimensão e diversidade como o nosso país.

Art. 89. As creches e pré-escolas existentes ou que venham a ser criadas deverão, no prazo de três anos, a contar da publicação desta Lei, integrar-se ao respectivo sistema de ensino.

- Outra preocupação é com relação à "integrar-se", no sentido de tornar-se parte integrante, incorporar-se.

Art. 91. Esta Lei entra em vigor na data de sua publicação.

Art. 92. Revogam-se as disposições das Leis $\mathrm{n}^{\mathrm{o}} \mathrm{S}$ 4.024, de 20 de dezembro de 1961, e 5.540, de 28 de novembro de 1968, não alteradas pelas Leis nos 9.131, de 24 de novembro de 1995 e 9.192, de 21 de dezembro de 1995 e, ainda, as Leis nos 5.692, de 11 de agosto de 1971 e 7.044, de 18 de outubro de 1982, e as demais leis e decretos-lei que as modificaram e quaisquer outras disposições em contrário. Brasília, 20 de dezembro de 1996.

Coube à Lei de Diretrizes e Bases da Educação Nacional no 9394 de 199638, complementar ações constitucionais trazendo a educação infantil para o interior da Educação Básica, como etapa do sistema educacional brasileiro, garantindo a esse nível de ensino assento no sistema escolar. As maiores alterações ficam no espaço da creche que passam a integrar o sistema educacional juntamente com pré-escolas: "As creches e pré-escolas existentes ou que venham a ser criadas 
deverão, no prazo de três anos, a contar da publicação dessa Lei, integrar-se ao respectivo sistema de ensino" (LDB, Título IX, Das Disposições Transitórias, art. 89). Diante destas questões, os municípios defrontaram-se com a enorme tarefa de integrar creches ao sistema de educação infantil.

Cabe lembrar que não é tarefa simples, pois os ajustes vão desde a definição do espaço físico à previsão de condições de adequação às necessidades infantis, a revisão de objetivos e funções de equipamentos que a tradição consagrou, a organização de programas de formação continuada para qualificar profissionais e à transferência ou definição dos recursos financeiros, materiais e humanos para a constituição de um sistema único de educação infantil.

KISHIMOTO ${ }^{30}$, conclui que: A Lei de Diretrizes e Bases da Educação Nacional ${ }^{38}$, ao estabelecer que a educação infantil é a primeira etapa da educação básica, gera orientações nacionais que configuram no Referencial Curricular de Educação Infantil 6,7,8, de 1998, entre as quais se destacam: "O direito das crianças a brincar, como forma particular de expressão, pensamento, interação e comunicação infantil" e a socialização das crianças por meio de sua participação e inserção nas mais diversificadas práticas sociais, sem discriminação de espécie alguma". Dessa forma o brincar e a socialização passam a constituir princípios norteadores do trabalho educativo.

\subsection{REFERENCIAL CURRICULAR NACIONAL PARA A EDUCAÇÃO INFANTIL}


A expansão da educação infantil no Brasil e no mundo tem ocorrido de forma crescente nas últimas décadas, acompanhando a intensificação da urbanização, a participação da mulher no mercado de trabalho e as mudanças na organização e estrutura das famílias. Por outro lado, a sociedade está mais consciente da importância das experiências na primeira infância, o que motiva demandas por uma educação institucional para crianças de zero a seis anos.

A conjunção desses fatores ensejou um movimento da sociedade civil e de órgãos governamentais para que o atendimento às crianças de zero a seis anos fosse reconhecido na Constituição Federal de 1988³. A partir de então, a educação infantil em creches e pré-escolas passou a ser, ao menos do ponto de vista legal, um dever do Estado e um direito da criança (artigo 208, inciso IV). O Estatuto da Criança e do Adolescente $^{41}$, de 1990, destaca também o direito da criança a este atendimento. Reafirmando essas mudanças, a Lei de Diretrizes e Bases da Educação Nacional38, Lei n 9.394, promulgada em dezembro de 1996, estabelece de forma incisiva o vínculo entre o atendimento às crianças de zero a seis anos e a educação.

De acordo com a $\operatorname{LDB}^{38}$ e considerando seu papel e sua responsabilidade na indução, proposição e avaliação das políticas públicas relativas à educação nacional, o Ministério da Educação e do Desporto propõe, por meio deste documento, um Referencial Curricular Nacional para Educação Infantil6,7,8.

Composto pôr uma coleção de três volumes, organizados da seguinte forma: um documento introdução, que apresenta uma reflexão sobre creches e pré-escolas no Brasil, situando e fundamentando concepções de criança, educação, de instituição e do profissional, que 
foram utilizadas para definir os objetivos gerais da educação infantil e orientaram a organização dos documentos de eixos de trabalho que estão agrupados em dois volumes relacionados aos seguintes âmbitos de experiência: Formação Pessoal e Social e Conhecimento de Mundo; um volume relativo ao âmbito de experiência Formação Pessoal e Social que contém o eixo de trabalho que favorece, prioritariamente, os processos de construção da Identidade e Autonomia das Crianças; um volume relativo ao âmbito de experiência Conhecimento de Mundo que contém seis documentos referentes aos eixos de trabalho orientados para a construção das diferentes linguagens pelas crianças e para as relações que estabelecem com os objetos de conhecimento: Movimento, Música, Artes Visuais, Linguagem Oral e Escrita, Natureza e Sociedade e Matemática.

Para Garantir o acesso e o bom aproveitamento deste material, o MEC coloca à disposição de cada profissional de educação infantil seu próprio exemplar, para que possa utiliza-lo como instrumento de trabalho cotidiano, consultá-lo, fazer anotações e discuti-lo com seus parceiros e/ou com os familiares das crianças usuárias das instituições.

A organização do Referencial possui caráter instrumental e didático, devendo os professores Ter consciência, em sua prática educativa, que a construção de conhecimentos se processa de maneira integrada e global e que há inter-relações entre os diferentes eixos sugeridos a serem trabalhados com as crianças.

Nessa perspectiva, o Referencial ${ }^{6,7,8}$ é um guia de orientação que deverá servir de base para discussões entre profissionais de um mesmo sistema de ensino ou no interior da instituição, na elaboração de projetos educativos singulares e diversos. 
Esses volumes pretendem contribuir para o planejamento, desenvolvimento e avaliação de práticas educativas que considerem a pluralidade e diversidade étnica, religiosa, de gênero, social e cultural das crianças brasileiras, favorecendo a construção de propostas educativas que respondam às demandas das crianças e seus familiares nas diferentes regiões do país. 


\subsection{REFERENCIAL CURRICULAR NACIONAL PARA A EDUCAÇÃO INFANTIL - RESUMIDO}

\subsubsection{APRESENTAÇÃO}

O Referencial ${ }^{54}$ é um guia de orientação que deverá servir de base para discussões entre profissionais de um mesmo sistema de ensino ou no interior da instituição, na elaboração de projetos educativos singulares e diversos. Ele contribui para o planejamento, desenvolvimento e avaliação de práticas educativas que considerem a pluralidade e diversidade étnica, religiosa, de gênero, social e cultural das crianças brasileiras, favorecendo a construção de propostas educativas que respondam às demandas das crianças e seus familiares nas diferentes regiões do país.

\subsubsection{CARACTERÍSTICAS}

Considerando-se as especificidades afetivas, emocionais, sociais e cognitivas das crianças de zero a seis anos, a qualidade das experiências oferecidas devem contribuir para o exercício da cidadania, embasadas nos princípios: de respeito à dignidade e direitos das crianças; o direito das crianças a brincar; o acesso aos bens sócio-culturais disponíveis; a socialização por meio de sua participação e inserção nas mais 
diversificadas práticas sociais e o atendimento aos cuidados essenciais associados à sobrevivência e ao desenvolvimento de sua identidade.

A estes princípios cabe acrescentar que as crianças têm direito, antes de tudo, de viver experiências prazerosas nas instituições.

\section{CRIANÇA}

A concepção de criança como de todo ser humano, é um sujeito social e histórico e faz parte de uma organização familiar que está inserida em uma sociedade, com uma determinada cultura, em um determinado momento histórico. É profundamente marcada pelo meio social em que se desenvolve, mas também o marca.

\section{EDUCAR}

A instituição de educação infantil deve tornar acessível a todas as crianças que a freqüentam, indiscriminadamente, elementos da cultura que enriquecem o seu desenvolvimento e inserção social. Cumpre um papel socializador, propiciando o desenvolvimento da identidade das crianças, por meio de aprendizagens diversificadas, realizadas em situações de interação.

\section{CUIDAR}

O cuidado do ser humano significa compreender como ajudar o outro a se desenvolver como ser humano. Cuidar significa valorizar e ajudar a desenvolver capacidades. É um ato em relação ao outro e si 
próprio que possui uma dimensão expressiva e implica em procedimentos específicos. Exige conhecimentos específicos, habilidades e instrumentos que extrapolam a dimensão pedagógica. Demanda a integração de vários campos de conhecimentos e a cooperação de vários profissionais. Atender às necessidades básicas e afetivas é também base para o desenvolvimento infantil.

\subsubsection{COMPONENTES CURRICULARES}

\subsubsection{CONTEÚDOS}

Os referenciais ${ }^{54}$ concebem os conteúdos, por um lado, como a concretização dos propósitos da instituição e, por outro, como um meio para que as crianças desenvolvam suas capacidades e exercitem sua própria maneira de pensar, sentir e ser, ampliando suas hipóteses a cerca do mundo ao qual pertencem e constituindo-se em um instrumento para compreensão da realidade.

CONCENTUAIS - Capacidades para operar com símbolos, idéias, imagens e representações que permitem atribuir sentido à realidade. Por exemplo: a criança chama o cachorro por AU-AU e todos os outros animais também, quando recebe novas informações diferencia o gato. Alguns conceitos serão apropriados na Educação Infantil. Outros não, e necessitarão de mais tempo. 
PROCEDIMENTAIS - referem-se ao saber fazer - construir instrumentos e estabelecer caminhos que possibilitem às crianças a realização de suas ações.Apropriar-se de "ferramentas" da cultura humana para viver. Saber manipular corretamente os objetos de uso cotidiano, por exemplo: vestir-se ou amarrar os sapatos, tão importante no processo de conquista da independência. Trabalhado muitas vezes, de forma articulada com conteúdos conceituais e atitudinais.

ATITUDINAIS - são os de função básica de socialização por este motivo, gerador de atitudes. Podem não ser trabalhados de forma consciente e intencional. Prática coerente, onde os valores, as atitudes e as normas que se pretende trabalhar estejam presentes, desde as relações entre as pessoas até a seleção dos conteúdos, passando pela própria forma de organização da instituição. Coerência entre o discurso dos educadores e a sua prática. A instituição nunca dará conta da totalidade do que há para ensinar.

\subsubsection{ORGANIZAÇÃo DOS CONTEÚDOS POR BLOCOS}

Situam-se os diferentes conteúdos dentro de um contexto organizador que explicita suas especificidades por um lado e aponta para a sua origem por outro. Por exemplo: ao ler uma história, o professor estará trabalhando não só a leitura, mas também, a fala, a escrita, a escuta. Os conteúdos podem estar contemplados em mais de um eixo -integração dos conteúdos e relação entre si. 


\subsubsection{SELEÇÃO DOS CONTEÚDOS}

Oferecem um repertório que possa auxiliar o desenvolvimento das capacidades colocadas nos objetivos gerais. Seleção e adequação conforme o grupo de crianças e suas necessidades para que sejam significativos para as crianças.

Integração entre conteúdos relacionados entre si, possibilitando que a realidade seja analisada por diferentes aspectos, sem fragmentá-la.

\subsection{ORIENTAÇÕES DIDÁTICAS}

São subsídios que remetem ao "como fazer", à intervenção direta do professor na sua promoção de atividades e cuidados, alinhados com uma concepção de criança e educação.

Explicitam os princípios gerais do eixo, organização do tempo, do espaço e dos materiais, observação, registro e avaliação.

\subsection{ORGANIZAÇÃO DO TEMPO}

Rotina: cuidados, brincadeiras e situações de aprendizagens orientadas devem ser os integrantes organizados do tempo didático. A organização do tempo pode estar dividida em 3 grandes modalidades:

- atividades permanentes (são as básicas de cuidados, aprendizagem e prazer - conteúdos constantes);

- seqüência de atividades (promove aprendizagem específica e definida); 
- projetos de trabalho (são conjuntos de atividades que trabalham com conhecimentos específicos, construídos a partir de um eixo de trabalho), por exemplo: elaborar um livro, uma criação, uma coleção.

\subsection{ORGANIZAÇÃO DO ESPAÇO E SELEÇÃO DOS MATERIAIS}

Fazem parte a sala e todos os espaços da escola, mais os externos, que deverão estar organizados, pois são instrumentos fundamentais para a prática educativa.

\subsection{OBSERVAÇÃO, REGISTRO E AVALIAÇÃO FORMATIVA}

Registrar os processos de aprendizagem das crianças, a qualidade das interações estabelecidas com outras crianças, funcionários e com o professor - acompanhar os processos de desenvolvimento. Fornecem uma visão integral e ao mesmo tempo de suas particularidades. Os registros diários são um rico material de reflexão e ajuda para o planejamento educativo.

Outras formas de registros: gravação em áudio e vídeo, produção das crianças ao longo do tempo, fotografias etc. A avaliação não tem o objetivo da promoção, nem mesmo para o acesso ao ensino fundamental.

Deve ser processual e destinada a auxiliar o processo de aprendizagem, fortalecendo a auto - estima das crianças. Tem a função de acompanhar, orientar, regular e redirecionar o processo como um todo (o que sabiam fazer e o que sabem até o momento - os avanços). A avaliação deve ser 
sistemática, formativa e contínua. 0 educador/ professor deve dar ciência aos pais em tempos regulares.

\subsection{4 ÂMBITOS E EIXOS DE TRABALHO}

\subsubsection{FORMAÇÃO PESSOAL E SOCIAL}

Saber o que é estável e o que é circunstancial em sua pessoa, conhecer suas características e potencialidades e reconhecer seus limites é central para o desenvolvimento da identidade e para a conquista da autonomia.

Desenvolvimento da identidade e da autonomia: é a capacidade das crianças terem confiança em si próprias e o fato de se sentirem aceitas, ouvidas, cuidadas e amadas, oferecem segurança para a formação pessoal e social = socialização.

IDENTIDADE =distinção, marca de diferença entre as pessoas, a começar pelo nome, seguido de todas as características físicas, modos de agir e de pensar e da história pessoal. Sua construção é gradativa e se dá por meio das interações sociais estabelecidas pela criança. 0 primeiro grupo é a família, depois as festas populares, a igreja, a creche e assim, de outros universos sociais.

A fonte original da identidade está naquele círculo de pessoas com quem a criança interage no início da vida. A participação da criança na instituição de educação infantil pode alargar o universo inicial, com vistas à possibilidade de conviverem com outras crianças e com adultos 
de origens e hábitos culturais diversos, de aprender novas brincadeiras, de adquirir conhecimentos sobre realidades distantes.

AUTONOMIA = é a capacidade de se conduzir e tomar decisões por si próprio, levando em conta, regras, valores, perspectiva pessoal bem como a do outro - é um princípio a ser alcançado com as crianças. Conceber uma educação em direção à autonomia significa considerar as crianças como seres com vontade própria, capazes e competentes para construir conhecimentos, e, dentro de suas possibilidades, interferir no meu em que vivem. Exercitando o autogoverno em questões situadas no plano das ações concretas, poderão gradualmente fazê-lo no plano das idéias e dos valores - a noção de reciprocidade e de cooperação nas crianças - para uma sociedade que se propõe a atender o bem comum, usufruindo de gradativa independência para agir, tendo condições de escolher e tomar decisões, participando do estabelecimento de regras e sanções.

O processo de construção da identidade e da autonomia depende da vivência de algumas experiências consideradas essenciais associadas à fusão e diferenciação, construção de vínculos e expressão da sexualidade.

Para aprender as crianças necessitam que haja interação com outras pessoas, mas também dos recursos de cada criança. Dentre estes recursos destacam-se a imitação, o faz-de-conta, a oposição, a linguagem e a apropriação da imagem corporal. 


\subsubsection{CONHECIMENTO DE MUNDO}

\section{MOVIMENTO}

A criança e o movimento: expressividade, equilíbrio e coordenação.

\section{MÚSICA}

O fazer musical e apreciação musical.

\section{ARTES VISUAIS}

O fazer artístico e apreciação em artes visuais.

\section{LINGUAGEM ORAL E ESCRITA}

Falar e escutar, escrita, leitura em ambiente alfabetizador.

\section{NATUREZA E SOCIEDADE}

Organização dos grupos e seu modo de ser, viver e trabalhar.

- os lugares e suas paisagens;

- objetos e processos de transformação;

- os seres vivos;

- os fenômenos da natureza.

\section{MATEMÁTICA}

Números e sistema de numeração, contagem, notação e escrita numéricas, operações, grandezas e medidas, espaço e forma. 


\section{REFERENCIAL CURRICULAR PARA A EDUCAÇÃO INFANTIL}

São dois âmbitos que compreendem eixos de trabalho, de acordo com o mapa a seguir, no qual ressalta-se que a construção de conhecimentos se processa de maneira integrada e global e que entre os âmbitos existem interrelações.

OBJETIVOS GERAIS

CONHECIMENTOS DE MUNDO

FORMAÇÃO PESSOAL E SOCIAL

MOVIMENTO LINGUAGEM ORAL E ESCRITA

MÚSICA NATUREZA E SOCIEDADE

ARTES VISUAIS MATEMÁTICA

OBJETIVOS E CONTEÚDOS

IDENTIDADE E AUTONOMIA

CRIANÇA DE ZERO A TRÊS ANOS

CRIANÇA DE QUATRO A SEIS ANOS

Cada eixo de trabalho constitui uma parcela significativa da produção cultural humana, abrangendo conhecimentos relacionados à atividades e valores, conteúdos conceituais e atitudinais. 


\subsection{LEI N. 10.172, 9 DE JANEIRO DE 2001}

Aprova o Plano Nacional de Educação e dá outras providências.

\subsubsection{HISTÓRICO}

A instalação da República no Brasil e o surgimento das primeiras idéias de um plano que tratasse da educação para todo o território nacional aconteceram simultaneamente. À medida que o quadro social, político e econômico do início deste século se desenhava a educação começava a se impor como condição fundamental para o desenvolvimento do País. Havia grande preocupação com a instrução, nos seus diversos níveis e modalidades. Nas duas primeiras décadas, as várias reformas educacionais, ajudaram no amadurecimento da percepção coletiva da educação como um problema nacional.

Em 1932, um grupo de educadores, 25 homens e mulheres da elite intelectual brasileira, lançou um manifesto ao povo e ao governo que ficou conhecido como "Manifesto dos Pioneiros da Educação". Propunham a reconstrução educacional, "de grande alcance e de vastas proporções... um plano com sentido unitário e de bases científicas...". 0 documento teve grande repercussão e motivou uma campanha que resultou na inclusão de um artigo específico na Constituição Brasileira de 16 de julho de 1934. 0 art. 150 declarava ser competência da União "fixar o plano nacional de educação, compreensivo do ensino de todos os graus e ramos, comuns e especializados; e coordenar e fiscalizar a sua 
execução, em todo o território do País". Atribuía, em seu art. 152, competência precípua ao Conselho Nacional de Educação, organizado na forma da lei, a elaborar o plano para ser aprovado pelo Poder Legislativo, sugerindo ao Governo as medidas que julgasse necessárias para a melhor solução dos problemas educacionais bem como a distribuição adequada de fundos especiais".

Todas as constituições posteriores, com exceção da Carta de 37, incorporaram, implícita ou explicitamente, a idéia de um Plano Nacional de Educação ${ }^{45}$. Havia, subjacente, o consenso de que o plano devia ser fixado por lei. A idéia prosperou e nunca mais foi inteiramente abandonada.

0 primeiro Plano Nacional de Educação ${ }^{45}$ surgiu em 1962, elaborado já na vigência da primeira Lei de Diretrizes e Bases da Educação Nacional, Lei no 4.024 , de 1961. Ele não foi proposto na forma de um projeto de lei, mas apenas como uma iniciativa do Ministério da Educação e Cultura, iniciativa essa aprovada pelo então Conselho Federal de Educação. Era basicamente um conjunto de metas quantitativas e qualitativas a serem alcançadas num prazo de oito anos. Em 1965, sofreu uma revisão, quando foram introduzidas normas descentralizadoras e estimuladoras da elaboração de planos estaduais. Em 1966, uma nova revisão, que se chamou Plano Complementar de Educação, introduziu importantes alterações na distribuição dos recursos federais, beneficiando a implantação de ginásios orientados para o trabalho e o atendimento de analfabetos com mais de dez anos.

A idéia de uma lei ressurgiu em 1967, novamente proposta pelo Ministério da Educação e Cultura e discutida em quatro Encontros 
Nacionais de Planejamento, sem que a iniciativa chegasse a se concretizar.

Com a Constituição Federal de 1988², cinqüenta anos após a primeira tentativa oficial, ressurgiu a idéia de um plano nacional de longo prazo, com força de lei, capaz de conferir estabilidade às iniciativas governamentais na área de educação. 0 art. 214 contempla esta obrigatoriedade.

Por outro lado, a Lei no 9.39438, de 1996, que "estabelece as Diretrizes e Bases da Educação Nacional", determina nos artigos 9o e 87, respectivamente, que cabe à União, a elaboração do Plano, em colaboração com os Estados, o Distrito Federal e os Municípios, e institui a Década da Educação. Estabelece ainda, que a União encaminhe o Plano ao Congresso Nacional, um ano após a publicação da citada lei, com diretrizes e metas para os dez anos posteriores, em sintonia com a Declaração Mundial sobre Educação para Todos.

Em dez de fevereiro de 1998, o Deputado Ivan Valente apresentou no Plenário da Câmara dos Deputados o Projeto de Lei no 4.155, de 1998 que "aprova o Plano Nacional de Educação". A construção deste plano atendeu aos compromissos assumidos pelo Fórum Nacional em Defesa da Escola Pública, desde sua participação nos trabalhos da Assembléia Nacional Constituinte, consolidou os trabalhos do I e do II Congresso Nacional de Educação - CONED e sistematizou contribuições advindas de diferentes segmentos da sociedade civil. Na justificação, destaca o Autor a importância desse documento-referência que "contempla dimensões e problemas sociais, culturais, políticos e educacionais brasileiros, embasado nas lutas e proposições daqueles que defendem uma sociedade mais justa e igualitária". Em 11 de fevereiro de 1998, o 
Poder Executivo enviou ao Congresso Nacional a Mensagem 180/98, relativa ao projeto de lei que "Institui o Plano Nacional de Educação". Iniciou sua tramitação na Câmara dos Deputados como Projeto de Lei no 4.173 de 1998, apensado ao PL no 4.155/98, em 13 de março de 1998. Na Exposição de Motivos destaca o Ministro da Educação a concepção do Plano, que teve como eixos norteadores, do ponto de vista legal, a Constituição Federal de 1988', a Lei de Diretrizes e Bases da Educação Nacional $^{38}$, de 1996, e a Emenda Constitucional no 14, de 1995, que instituiu o Fundo de Manutenção e Desenvolvimento do Ensino Fundamental e de Valorização do Magistério. Considerou ainda realizações anteriores, principalmente o Plano Decenal de Educação para Todos, preparado de acordo com as recomendações da reunião organizada pela UNESCO e realizada em Jomtien, na Tailândia, em 1993. Além deste, os documentos resultantes de ampla mobilização regional e nacional que foram apresentados pelo Brasil nas conferências da UNESCO constituíram subsídios igualmente importantes para a preparação do documento. Várias entidades foram consultadas pelo MEC, destacando-se o Conselho Nacional de Secretários de Educação CONSED e a União Nacional dos Dirigentes Municipais de Educação UNDIME. Os projetos foram distribuídos às Comissões de Educação, Cultura e Desporto; de Finanças e Tributação; e de Constituição, Justiça e de Redação. Na primeira, é Relator, o Deputado Nelson Marchezan.

Este Plano Nacional de Educação define por conseguinte:

- diretrizes para a gestão e o financiamento da educação; - diretrizes e metas para cada nível e modalidade de ensino e . diretrizes e metas para a formação e valorização do magistério e demais profissionais da educação, nos próximos dez anos. 
Tratando-se de metas gerais para o conjunto da Nação, será preciso, como desdobramento, adequação às especificidades locais e definição de estratégias adequadas, a cada circunstância, elaboração de planos estaduais e municipais.

\subsubsection{OBJETIVOS E PRIORIDADES}

Em síntese, o Plano tem como objetivos:

- a elevação global do nível de escolaridade da população;

- a melhoria da qualidade do ensino em todos os níveis;

- a redução das desigualdades sociais e regionais no tocante ao acesso e à permanência, com sucesso, na educação pública e democratização da gestão do ensino público, nos estabelecimentos oficiais, obedecendo aos princípios da participação dos profissionais da educação na elaboração do projeto pedagógico da escola e a participação das comunidades escolar e local em conselhos escolares ou equivalentes.

Considerando que os recursos financeiros são limitados e que a capacidade para responder ao desafio de oferecer uma educação compatível, na extensão e na qualidade, à dos países desenvolvidos precisa ser construída constante e progressivamente, são estabelecidas prioridades neste plano, segundo o dever constitucional e as necessidades sociais.

A educação infantil é a primeira etapa da Educação Básica. Ela estabelece as bases da personalidade humana, da inteligência, da vida emocional, da socialização. As primeiras experiências da vida são as que marcam mais profundamente a pessoa. Quando positivas, tendem a 
reforçar, ao longo da vida, as atitudes de autoconfiança, de cooperação, solidariedade, responsabilidade.

As ciências que se debruçaram sobre a criança nos últimos cinqüenta anos, investigando como se processa o seu desenvolvimento, coincidem em afirmar a importância dos primeiros anos de vida para o desenvolvimento e aprendizagem posteriores.

A pedagogia mesma vem acumulando considerável experiência e reflexão sobre sua prática nesse campo e definindo os procedimentos mais adequados para oferecer às crianças interessantes, desafiantes e enriquecedoras oportunidades de desenvolvimento e aprendizagem. A educação infantil inaugura a educação da pessoa.

E tem oferecido grande suporte para a educação formular seus propósitos e atuação a partir do nascimento. Essa educação se dá na família, na comunidade e nas instituições. As instituições de educação infantil vêm se tornando cada vez mais necessárias, como complementares à ação da família, o que já foi afirmado pelo mais importante documento internacional de educação deste século, a Declaração Mundial de Educação para Todos (Jomtien, Tailândia, 1990).

Considera-se, no âmbito internacional, que a educação infantil terá um papel cada vez maior na formação integral da pessoa, no desenvolvimento de sua capacidade de aprendizagem e na elevação do nível de inteligência das pessoas, mesmo porque inteligência não é herdada geneticamente nem transmitida pelo ensino, mas construída pela criança, a partir do nascimento, na interação social mediante a ação sobre os objetos, as circunstâncias e os fatos.

0 que este plano recomenda é uma educação de qualidade prioritariamente para as crianças mais sujeitas à exclusão ou vítimas 
dela. A expansão que se verifica no atendimento das crianças de seis e cinco anos de idade, conduzirá invariavelmente à universalização, transcendendo a questão da renda familiar.

Assegurar que, em dois anos, todos os Municípios tenham definido sua política para a educação infantil, com base nas diretrizes nacionais, nas normas complementares estaduais e nas sugestões dos referenciais curriculares nacionais.

Instituir mecanismos de colaboração entre os setores da educação, saúde e assistência na manutenção, expansão, administração, controle e avaliação das instituições de atendimento das crianças de zero a três anos de idade.

Estabelecer um Programa Nacional de Formação dos Profissionais de educação infantil, com a colaboração da União, Estados e Municípios, inclusive das universidades e institutos superiores de educação e organizações não-governamentais, que realize as seguintes metas:

a) Em cinco anos, todos os dirigentes de instituições de educação infantil possuam formação apropriada em nível médio (modalidade Normal) e, em dez anos, formação de nível superior;

b) Em cinco anos, todos os professores tenham habilitação específica de nível médio e, em dez anos, 70\% tenham formação específica de nível superior.

KISHIMOTO ${ }^{30}$, conclui, o Brasil demonstrou um caminho peculiar ao introduzir brinquedotecas no interior de escolas de educação infantil. A inclusão de brinquedos no interior das escolas exige uma configuração própria, distinta de outros de natureza cultural, requer uma organização destes de forma peculiar, sem sofisticação, adaptada aos interesses e necessidades de crianças de quatro a seis anos, que favoreça a recriação 
da brincadeira, a cooperação e expressão da criança, paralelamente à educação educativa supervisionada.

Outra peculiaridade é o pouco uso das linguagens expressivas de forma integrada (artes visuais, plásticas, musica, dança, teatro, motricidade e literatura infantil) nas práticas pedagógicas. Essa característica tem suas raízes na ausência de tais componentes nos cursos de formação de professores de educação infantil. Só recentemente os cursos de pedagogia reformularam seus currículos para introduzi-los.

No fim do século XX, a educação infantil destinada a crianças de zero a seis anos enfrenta desafios: integrar o cuidado à educação, o que equivale integrar creches no sistema de ensino com todas suas conseqüências, municipalizar a rede de escolas infantis, integrar experiências envolvendo crianças de zero a seis e até dez anos eliminar as classes de alfabetização, refletir sobre experiências apressadas da inclusão de crianças de seis anos no ensino fundamental criando problemas de locus dessa educação: ensino fundamental versus educação infantil ou de antecipação de escolaridade.

Se o nível de formação de profissionais da educação infantil no Brasil é bastante baixo como indicam dados de 1998, cerca de $25 \%$ com formação superior, a qualificação profissional é tarefa urgente, desde que não se iludam com modelos aligeirados ${ }^{29}$.

Supõem-se que em nosso país, a grande maioria dos profissionais de creches ainda permaneça com formação correspondente ao ensino fundamental.

Garantir o direito à educação infantil e o dever do Estado em oferecer um sistema integrado de educação que inclua o cuidar e o 
educar sem omitir o direito da criança ao brinquedo, à brincadeira e à socialização concomitantemente à construção do conhecimento parece ser a aspiração para o século XXI4 .

\subsection{EDUCAÇÃO EM SAÚDE}

As ações educativas em saúde para escolares no Brasil, segundo OLIVEIRA ${ }^{43}$, 1997, sempre estiveram presentes nos discursos oficiais desde a Primeira República, em 1889. Orientavam-se por princípios biologizantes, individualizantes, pela transmissão de hábitos e comportamentos considerados saudáveis. Tais procedimentos chegam desacreditados aos anos 50-60. Estudos realizados pela OPS/OMS, nos países da América Latina, passavam a orientar, já nos anos 50, um novo pensar e agir em relação aos problemas de saúde da população. A Educação para Saúde, integrante das ações de atenção primária de saúde, permeia o debate e atravessa os anos 60, encontrando respaldo internacional na Conferência de Alma-Ata, em 1978. A saúde, como direito social, vinculada às condições de vida é colocada no patamar da multicausalidade, conferindo-se ao biologismo uma menor responsabilidade no processo saúde /doença, assumindo as práticas educativas em saúde uma orientação que colocava grupos sociais como alvo das ações, no contexto da saúde coletiva.

Este estudo se propôs a identificar as concepções de Educação em Saúde, as dificuldades e os desafios presentes nas ações educativas em saúde para escolares, decorrentes da evolução das práticas sanitárias na sociedade brasileira, com maior ênfase após os anos 70, haja vista a 
inflexão nos princípios doutrinários no setor saúde, principalmente após a 8a Conferência Nacional de Saúde (CNS), quando se oportunizou a busca da concretização de propostas colocadas para o setor desde a $3^{\text {a }}$ CNS, em 1963 e melhor discutidas, analisadas e elaboradas ao momento

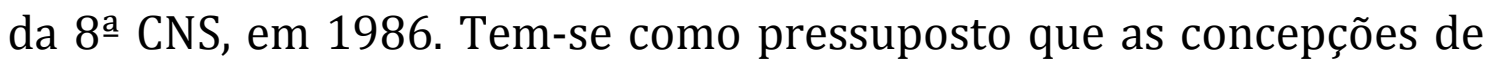
Educação para Saúde no Brasil encontram-se espelhadas nas políticas sociais e, neste caso particular, nas políticas de saúde e educação, tendo a criança como alvo prioritário, constituindo-se, a partir dos anos 70, e com maior ênfase, a partir dos anos 80, como instrumento de conscientização e produção de auto-conhecimento, embasada na açãoreflexão-ação, no questionamento entre sujeito-sujeito para conquista de melhores níveis de saúde e fortemente dirigida para a promoção à saúde, objetivando melhoria na qualidade de vida do cidadão, devendo prepara-lo para a capacidade de refletir sobre suas necessidades e criticar sua realidade, sentindo-se responsável também pelo seu bemestar enquanto ser social. Ainda, uma prática educativa que identifica os aspectos econômicos, culturais e ambientais como interveniente no processo saúde-doença; que exige mudança de atitude do profissional de saúde no acompanhamento e tratamento da doença, devendo conhecer a realidade sócio-cultural-ambiental na qual ele prestará serviços e que além de competência técnica, esteja imbuído de compromisso social. Exige também mudança do próprio sistema de saúde, devendo conceder ao cidadão seus direitos sociais em forma de qualidade de atendimento com vistas a suprir interesses de uma dada coletividade.

A análise dos documentos selecionados, por OLIVEIRA ${ }^{43}$, foi deixando clara a existência de uma trajetória das ações educativas em 
saúde para escolares no Brasil, com duas concepções básicas demarcadoras de cinco períodos históricos de acordo com pequenas variações das concepções básicas.

As concepções básicas configuram dois grandes momentos históricos da Educação para a Saúde no país: um que, teoricamente, ressona no passado - o período da Educação Sanitária e, o outro, que desperta ancorado num referencial teórico mais ampliado e que se propõe a contribuir no sentido de alcançar maiores e melhores resultados no nível de saúde da população - o período da Educação em Saúde. A transição entre os modelos se deu, e vem se dando, num embate entre um passado que se enraizou e um presente que se descortina. 0 período de maturação exige mediação, não para se abandonar o velho, mas para ampliá-lo, moldá-lo e a ele incorporar elementos necessários e considerados hoje imprescindíveis ao debate e entendimento do processo saúde-doença.

\section{1ํa República (1889) - anos 60}

$\mathrm{Na}$ análise das ações educativas em saúde para escolares no contexto da Educação Sanitária, no período que vai de 1889 aos anos 60, distinguiu-se três concepções, existindo uma proposta de Educação Sanitária, no período que vai de 1889 aos anos 60, distinguiu-se três concepções, existindo uma proposta de Educação Sanitária normativa, prescritiva e com características de inspeção, destinada a moralizar e higienizar as pessoas e as cidades, numa posição de ataque ao germe e ao vetor. 
A concepção higienista-eugenista (1889-1929), repousava numa proposta circunscrita ao modelo biomédico em que o agente, 0 vetor e a responsabilidade individual pela saúde eram elementos sempre lembrados nas práticas sanitárias. 0 avanço do conhecimento científico, refutando a teoria miasmática, permitia à Educação Sanitária reforçar a realidade biológica do homem e as ações, de cunho eugenista, deveria proporcionar ao país uma raça sadia e com capacidade produtiva.

O médico era responsável pelo policiamento das ações higienistas, pela cura e controle das doenças. Era incumbido de reorganizar a sociedade. Deveria conduzir as propostas e reformas no setor saúde e transmitir aos professores as informações, normas e valores que deveriam ser aceitos e colocados em prática na sociedade e, principalmente, no universo escolar. As ações deveriam ser praticadas antes que se compreendessem suas razões científicas.

A educação Sanitária era instrumental importante do Projeto Higiênico. A inspeção médica e a normatização da vida dos alunos eram práticas rotineiras no universo escolar.

A concepção sanitarista (1930-1950) indica uma ampliação da concepção anterior, incorporando questões de saneamento como intervenientes no processo saúde-doença, imprimindo maior cientificidade ao discurso sanitário; mostrava-se como enfrentamento público das seqüelas das questões sociais, numa visão da medicalização do ambiente.

Na 1ạ Conferência Nacional de Saúde-1941, a infância e a adolescência se mostraram como prioridade política, no governo de Vargas, devendo ser alvos da Educação Sanitária, entendida, neste 
momento, como se percebeu nos depoimentos do tema Educação Sanitária na Escola, no $1^{\text {o }}$ Congresso Nacional de Saúde Escolar, realizado em 1942.

A Educação Sanitária se mostrava como elemento básico da prevenção. 0 pensamento desenvolvimentista, dos anos 50, permitia emergir o discurso preventivista, dando sinais de avanço no conhecimento em saúde, quando os aspectos econômicos e sociais começavam a ser vistos como elementos determinantes do processo saúde-doença, mas o enfoque biológico/individual no combate à doença ainda era marcante. A Educação Sanitária se mostrava discursiva, mas não sanitária - porque não orçamentária, visto o declínio das ações de saúde pública já no final dos anos 50 .

Nos anos 60, se configurou a concepção higienistaracionalizadora. As ações em saúde para escolares se desfiguravam e se apresentavam sem muitos detalhes, do que podemos deduzir o seu esvaziamento. Suas informações panfletárias voltavam-se às doenças transmissíveis e não se adequavam às diferentes problemáticas sanitárias das distintas regiões do país.

A racionalização dos serviços, entendida de forma diferenciada pelo governo e pelos sanitaristas, era a meta desejada.

Neste momento de esvaziamento das práticas de Educação Sanitária, acontecia a 3a Conferência Nacional de Saúde, em 1963. Em seus Anais evidencia-se o conceito de saúde defendido naquele momento e que seria retomado na $8^{a} \mathrm{CNS} / 86$. A questão econômica era colocada como fonte geradora da doença e (re)nascia a medicina como ciência social. Em relação à Educação Sanitária não se define com clareza o que se entendia por tal expressão. 0 papel subalterno que a educação 
para saúde ocupava passava por um período de desbotamento em busca de um processo melhor instrumentalizado.

Na 4a CNS, realizada em 1967, esperava-se que os educadores saíssem do encontro mais sanitaristas e os sanitaristas mais educadores. Em relação à Educação em Saúde para escolares, não houve uma posição definida. Neste período, a Educação Sanitária na escola atendia somente tópicos de higiene e saúde nos programas de Ciências e Biologia, determinada pelo Bureau Internacional de Educação de Saúde de 1946.

A Educação Sanitária, até os anos 60, se arrastou sempre normativa, individualista, biologicista e pouco enfatizando os aspectos sociais. Pode-se acreditar que era característica da época, conivente com a qualidade do conhecimento técnico-científico-econômico que até ali avançara. Concebida até então numa concepção mecanicista de saúde, onde corpo e mente se apresentassem nitidamente separados e os aspectos psicológicos, sociais e ambientais da vida humana fossem negligenciados, por não serem, no momento, passíveis de investigação e experimentação, passava a ser alvo de crítica e reconstrução, considerada como relação entre sujeitos e entendida como algo que é inerente às relações sociais.

Num conceito mais ampliado de saúde, a Educação Sanitária parecia se abrir para desempenhar um papel estimulador no processo de formação de uma consciência sanitária mais crítica, se propondo a ser instrumento de conscientização dos vários grupos sociais para conquistar os demais elementos condicionantes da qualidade de vida.

Resultante de reflexões e questionamentos sobre os reais objetivos da Educação Sanitária sentiu-se a necessidade de se modificar a terminologia para bem caracterizar a nova mentalidade. 0 termo 
Educação em Saúde começa a ser incorporado nos discursos oficiais e utilizado com mais freqüência nas publicações científicas e na fala dos sanitaristas.

O médico, que até então era considerado o líder das práticas sanitárias, é estimulado a integrar-se, justamente com demais profissionais da saúde, em equipe multiprofissional, haja vista a saúde ser entendida como resultante de multifatores, e não decorrente das ações e serviços do setor saúde somente, no combate à doença.

\section{Anos 70 - anos 90}

Neste momento de inflexão doutrinária do setor saúde e na perspectiva de novas práticas sanitárias, os setores educação e saúde deveriam aliar-se, configurando uma área de parceria. Os anos 70 foram um período marcado pelo interesse nos instrumentais de ensino, em destaque, os audio-visuais e a abordagem ao método de projetos. E então se estabelecia a concepção tecnicista da Educação em Saúde.

Os princípios acreditados e debatidos na 5a CNS, em 1975, foram proteção e recuperação da saúde, através de investimentos na área de saneamento básico e nutrição. As ações educativas em saúde para escolares encontravam-se imersas, de forma pálida, na educação alimentar, imunização e combate às doenças infecciosas e parasitárias, em especial, o combate à esquistossomose, através de publicações. Estas ações se faziam acompanhar pela inspeção e fichamento médico dos escolares.

No momento da realização da $5^{a}$ CNS/75 já se encontrava em vigor a Lei $\mathrm{n}^{\circ} 5.692 / 71$ que regulava o ensino de $1^{\text {o }}$ e $2^{\circ}$ Graus, e com 
caráter de obrigatoriedade para o ensino da saúde, determinado pelo art. $7 \stackrel{0}{ }$.

O parecer 2.264/74 trazia recomendações e sugestões para o desempenho das atividades de Educação em Saúde na escola. Embora preconizando saúde integral orientava para ações prioritariamente voltadas para o indivíduo. Uma teoria acertada, mas uma proposta prática um tanto distante da teoria proposta. Mas era o momento da educação antes fortemente domesticadora, procurava espaço para, agora, configurar-se como educação estimuladora.

O interesse pela Educação em Saúde se evidenciava no tema Situação atual do controle das grandes endemias, na 6 ${ }^{\text {a }} \mathrm{CNS}$, realizada em 1977. As ações de Educação em Saúde se encontravam em posição descrédito, dado o comportamento imediatista do alívio da dor e do sofrimento. Mas o comportamento da comunidade se encontrava numa relação direta com as práticas do sistema e dos profissionais de saúde, evidentemente. 0 interesse pela Educação em Saúde permanecia no nível das intenções.

Os passos sócio-políticos se davam lentamente, mas mesmo assim, encontravam o país, no período da 7a CNS, em 1980, um pouco mais aberto para as questões sociais. Naquele momento histórico, o Brasil confirmava acordos internacionais em saúde, em destaque, o de AlmaAta.

Algumas ações presentes no universo escolar foram alvos de debate. A merenda-estabelecida nos períodos anteriores - era privilegiada como ação básica escolar; e serviços de odontologia deveriam dar destaque a medidas de promoção de saúde com ênfase no desenvolvimento de ações de caráter preventivo e educativo. 
Nesta conferência não há recomendações claras e precisas para a Educação em Saúde, encontrando-se à deriva, arrastada por correntes de natureza política. Era considerado apoio para todas as atividades, não tendo, porém, um espaço definido nem assegurado ${ }^{10}$. Ao professor, era a crença do período, cabia a responsabilidade pela Educação em Saúde na escola.

Nesse emaranhado de idas e vindas a Educação em Saúde não encontrava seu ponto de referência.

Era chegado o momento de se operar mudanças, não partir de Leis e resoluções, mas a partir de uma atitude mental desenhada no contexto da realidade brasileira. Também era chegado o momento de deflagrar o processo que se desenhava e colocar em patamares de igualdade as ações de promoção, prevenção e assistência. De acordo com DONNANGELO ${ }^{20}$, era um caminho sem volta. Dentre os vários espaços que se descortinavam para as práticas de saúde coletiva, situava-se a escola, dentre as clientelas, estavam os escolares.

Tendo como substrato o conceito mais ampliado de saúde e acreditando-se que a educação se dá nas mais variadas formas de relações sociais, se vislumbra a Educação em Saúde como uma prática social, numa perspectiva de ação-reflexão, circunscreve os elementos necessários à manutenção da saúde, através da promoção e proteção, e prevenção da doença; considera a sua globalidade, considerando a saúde numa perspectiva integral. Considera ainda os conflitos presentes nas relações sociais, preparando e capacitando os indivíduos/grupos sociais a conquistarem, enquanto cidadãos, o seu direito à saúde. Ainda, identifica os pontos chaves do problema, estimula os indivíduos/grupos sociais a se perguntarem o porquê das coisas. Emerge a concepção 
crítica da Educação em Saúde, trazendo em seu bojo uma prática participativa e que adota a metodologia da problematização, sendo também conhecida como educação popular em saúde. Tal prática, envolvendo o Estado no setor saúde representado pelo Sistema Único de Saúde (SUS), e a sociedade civil, em seus diferentes níveis, traz como conseqüências individuais, aluno constantemente ativo, formulando perguntas, expressando percepções e opiniões; aprendizagem ligada a aspectos significativos da realidade; desenvolvimento das habilidades intelectuais de observação, análise, avaliação, compreensão, extrapolação, etc. no âmbito social, população conhecedora de sua própria realidade, cooperação na busca de soluções a problemas comuns, criação de tecnologia viável e culturalmente compatível, dentre outras.

Na 8a CNS, as questões de Educação em Saúde encontravam-se embutidas nas ações de atenção primária. Preconizava-se a Educação em Saúde para escolares num outro enfoque. 0 alvo passava a ser a criança em idade escolar; os conteúdos-debatidos dentro de sua realidade epidemiológica e de suas necessidades socioeconômicocultural-ambiental; a metodologia-participação, onde crianças, professores e profissionais, normalmente da área biomédica, passavam a serem vistos como sujeitos interativos do processo educativo em saúde, devendo também considerar os aspectos afetivos, cognitivos e sociais, rompendo com o modelo biomédico na concepção da saúde.

A segunda metade dos anos 80 mostrou-se rica em encontro, à nível nacional, interessados não só em teorizar a questão, mas em propor e construir metodologias, buscar conteúdos e estratégias que viessem fomentar e promover a prática da Educação em Saúde. Com 
destaque, realizou-se o $6^{\circ}$ Congresso Brasileiro de Saúde Escolar (CBSE), tendo como ponto alto do encontro a promoção da saúde ${ }^{44}$. Enfatizando o direito à saúde e a cidadania, buscava estimular educadores e demais profissionais da área da saúde a melhor se articularem em prol de resultados mais concretos em benefício da criança em idade escolar.

Nos Anais do 7ํㅡㄹ CBSE, realizado em 1989, percebe-se uma maior produção nas questões voltadas para a Educação em Saúde em detrimento da assistência. Mas trabalhos apresentados mostram que a Educação em Saúde ainda se orientava por métodos tradicionais, por atitudes higienistas, numa visão fragmentada de saúde.

A ênfase à multiprofissionalidade e interdisciplinaridade defendida na $8^{\text {a }} \mathrm{CNS} / 86$ e nos $6^{\circ}$ / 7ํㅡㄹ $\mathrm{CBSE}$, se estendeu ao tema central do 8o CBSE, realizado em 1991: A saúde Escolar $e$ a ação multiprofissional na construção da cidadania. Os assuntos debatidos estiveram relacionados às drogas, doenças sexualmente transmissíveis, aborto, os quais foram tidos como mais que questões médicas, questões também de cunho educacional. O 8 CBSE acontecia num momento em que a conjuntura vivida pelo país se caracterizava por uma crise que demandava ajustes estruturais. Nessa mesma conjuntura, acontecia, em 1992, a 9a CNS.

A 9a CNS preocupava-se em ratificar as propostas defendidas na $8^{\mathrm{a}}$ CNS. Permitia à sociedade brasileira avaliar a oferta de serviços e a situação de saúde. Nessa avaliação, crianças e adolescentes tornavamse alvo nas ações de atenção primária resultante da nova doutrina defendida pelos intelectuais e referendada pelo poder estatal. 
Os painelistas da conferência $A$ Saúde da Criança: prioridade nacional? Defendiam que a criança deve ser apontada oficialmente e de fato como prioridade nacional, deixando de ser mudanças estruturais apenas em momentos críticos da política brasileira (9aNS,1992). As questões educativas em saúde para escolares apresentavam-se de forma diluída nas questões de atenção primária, nas discussões e nas conferências sobre participação $\mathrm{x}$ controle social e informação $\mathrm{x}$ tecnologias apropriadas ao novo modelo sanitário situada mais como um desafio do que de ações propostas.

As práticas de Educação em Saúde no contexto da saúde escolar se mostravam como uma das modalidades de atividades no campo da saúde coletiva. A Lei no 8.080/90, que criou o Sistema Único de Saúde, termina por inspirar a formulação do Estatuto da Criança e do Adolescente em 1991, fortalecendo a necessidade da contribuição dos profissionais de saúde nas ações educativas em saúde na escola, referenciando ao setor saúde tal responsabilidade.

Grande parte das idealizações do Estatuto da Criança e do Adolescente e da 9a CNS se mostraram evidentes no 9o CBS, através dos debates e das ações desenvolvidas, mostradas pelas experiências realizadas em algumas cidades brasileiras.

Consideravam os profissionais de saúde, nas questões de saúde escolar, nesta 9a $\mathrm{CBSE} / 1992$, que nem sempre se podem alterar as condições socioeconômicas, mas ações preventivas e principalmente educativas podem contribuir para mudança de comportamento para minimizar o avanço da doença e reduzir agravos. 
Percebe-se um significativo interesse pelo planejamento e avaliação das ações em saúde para escolares. Um aspecto importante a destacar é a questão da abordagem ao ambiente de vida das pessoas/grupos sociais. Esta abordagem mostrou-se como o novo deste evento. As condições do ambiente de vida sobre a qualidade de vida das pessoas vêm se mostrando como elemento imprescindível no debate das questões da saúde e da doença fazendo-se presente na discussão das questões da saúde na escola.

As idas e vindas no período pós anos 70 evidenciam um descompasso entre o tempo de pensar e o tempo de agir. As mudanças avançam timidamente, havendo um déficit na operacionalização das ações. 0 velho que vem se tornando novo, conquistando novos espaços, avança, teoricamente, mesmo que lentamente, tateante e embasado numa visão integral de saúde, construindo-se numa prática mesclada entre três concepções identificadas nesse estudo: concepção higienistaeugenista, tecnicista e crítica, como conseqüência de algumas dificuldades e desafios que se colocam tanto no setor saúde quanto na educação, próprios de um processo de construção de um novo modelo. 


\subsection{PAPEL PROFISSIONAL DOS EDUCADORES DE SAÚDE}

\section{Nos Estados Unidos}

O projeto intitulado Delineamento do Papel Profissional dos Educadores de Saúde, patrocinado pelos U.S. Centers for Disease Control, nos Estados Unidos, representa até o momento o esforço mais expressivo para identificar tecnicamente os elementos que caracterizam a prática da educação em saúde ${ }^{9,15}$. Esse projeto fundamentou-se em trabalhos anteriores, apresentados por comissões nacionais, organizadas com vistas a especificar o conteúdo e os padrões de programas de treinamento profissional ${ }^{9}$. 


\section{No Brasil}

No Brasil, o estudo mais significativo que se fez, a respeito desse mesmo assunto, foi sobre o papel profissional dos educadores de saúde das Secretarias da Saúde do Estado e da Prefeitura de São Paulo ${ }^{50}$. Antes de sua realização, sempre com o patrocínio da OPAS/OMS, desenvolveuse um Seminário em Itu, no qual participaram educadores de saúde do Estado e da Prefeitura de São Paulo. Compareceram a esse encontro GREEN 25 e CLEARY15, especialista responsável pelo estudo que, nos Estados Unidos, atingiu as várias comissões já mencionadas. As recomendações desse Seminário e os resultados desse estudo foram divulgados em reuniões internacionais, realizadas em Houston e em Helsinski, assim como em artigos publicados. Resumidamente, o estudo realizado no Brasil mostra que todas as competências técnicas, identificadas e aceitas por profissionais nos Estados Unidos, corresponderam inteiramente ao modo de pensar e de atuar de seus colegas brasileiros. No estudo realizado em São Paulo nada foi proposto no sentido de cancelar ou acrescentar.

No momento, a principal preocupação dessa área de ação não é mais a inexistência de um campo específico de conhecimento técnicocientífico, como sucedeu nos primórdios da educação em saúde no Brasil (1925), mas a incapacidade política de implantar atividades educativas racionalmente planejadas.

A experiência junto à Secretaria de Estado da Saúde de São Paulo deu a oportunidade de analisar as políticas de ação referentes aos programas existentes. Verificou-se que a palavra educação, freqüentemente mencionada nos documentos oficiais, não passava de uma abstração incômoda. Nunca expressou uma proposta séria das 
autoridades administrativas que, em geral, tendiam a fundamentar suas ações no modelo biomédico de intervenção, com ênfase na doença e não na saúde. Sabe-se, entretanto, que a abordagem biomédica representa apenas uma das cinco formas de intervenção social no cenário da saúde pública, sendo as outras: a abordagem da mudança de comportamento, a abordagem educativa, a abordagem centralizada no cliente e a abordagem societária, cada qual buscando a consecução de determinados objetivos e, para tanto, recorrendo a pressupostos teóricos e conceituais e a especialistas provenientes de vários campos de conhecimento científico. 0 planejamento se realiza, portanto, de acordo com a lógica circunstancial das necessidades específicas que emergem em diferentes ambientes.

As atividades de educação em saúde têm utilizado o esquema de planejamento proposto por GREEN; KREUTER ${ }^{26}$, PRECEDE (o mais amplamente aplicado em várias partes do mundo) e, dentro dele, durante o desenvolvimento de programas educativos na fase do diagnóstico administrativo, modelos como o CAHP (conhecimentos, atitudes, habilidades e práticas da população-alvo), crenças em saúde, oportunidades de aprendizagem, entre outros. Todo esse conjunto teórico-prático diz respeito a um aqui agora, que se prende basicamente a programas de saúde em desenvolvimento, já se disse, em locais de trabalho, em escolas, em ambientes clínicos ou na comunidade. As atividades educativas, como meio de alcançar determinados fins, representam uma parte do conjunto de atividades dos programas de saúde que, conforme a natureza do problema, exigem um grau maior ou menor desse tipo de ações técnicas. Contudo, todos eles precisam, muito embora nem sempre se reconheça, da colaboração de um especialista. 
Note-se que do ponto de vista da educação em saúde, o ambiente de trabalho e aqueles que nele atuam têm muito a ver com os objetivos propostos por essa forma de intervenção. Os profissionais se relacionam diretamente com pessoas que já freqüentam ou que se pretende que venham a freqüentar determinados programas.

As ações que dizem respeito às atividades da promoção em saúde são bastante distintas. Seus objetivos afastam-se das pressões cotidianas do aqui $e$ agora de programas de saúde pública, buscando a participação de outras pessoas, cuja atuação se processa fora do espaço tradicional onde os programas são em geral implementados. Por essa razão, não poderiam se prender apenas ao esquema teórico PRECEDE e àqueles modelos acima referidos, CAHP, crenças em saúde, oportunidades de aprendizagem, entre outros. Acompanhando essa emergente necessidade de reformulação da atuação profissional, GREEN; KREUTER ${ }^{26}$ buscaram justificar a complementação do espaço técnico apresentado no esquema PRECEDE, mediante o esquema PROCEDE. Ao fazê-lo definiram e classificaram as novas propostas de atuação técnica da educação e da promoção em saúde, explicando a diferença dos objetivos dessas duas sub-partes de uma mesma, porém, mais completa, intervenção social. Também estudaram as razões históricas e epidemiológicas que as justificaram a partir do século XIX.

0 fato é que, em qualquer sistema de saúde, não se pode conceber o planejamento da política de ação, sem antes considerar as premissas do planejamento educativo em cada uma das duas vertentes acima referidas - educação e promoção em saúde. Se isso ocorrer, a prática subseqüente será equivocada e, portanto, ilógica no que diz respeito às necessidades da população-alvo que se pretende alcançar. 
Do ponto de vista da evolução histórica de todo esse processo educativo, o Seminário realizado em 1991 em Sundsvall, na Suécia, tornou mais evidentes os mecanismos de intervenção que podem ser utilizados na prática da promoção em saúde. Com o objetivo de passar da teoria à prática, o modelo HELPSAM-Health Promotion Strategy Analysis Model, descreve sete estratégias a considerar quando se recorre a esse tipo de abordagem ${ }^{14}$. São elas: desenvolvimento de políticas de ação, regulamentos em saúde (leis e normas), reorientação de organizações (institucionalização de novas atividades), advocacia (aumento do interesse público), alianças e mediações (informação e comunicação), fatores que possibilitam o comportamento em saúde e, finalmente, mobilização e aumento do poder mediante a participação e o envolvimento ativo. Cada uma deve ser definida em função dos seguintes elementos: tipo de enfoque, atores, alvos e níveis de arena, procedimentos/instrumentos e resultados esperados.

O modelo HELPSAM representa um valioso instrumento analítico para identificar as estratégias acessíveis e outros elementos essenciais à implementação de ações concretas no que diz respeito à promoção em saúde. Oferece uma visão panorâmica sobre a combinação de diferentes estratégias, mostrando que, além das medidas mais diretamente relacionadas ao componente educativo de programas de saúde, outras precisam ser concomitantemente planejadas, desenvolvidas e avaliadas. Essas assumem um caráter político muito mais intenso do que aquele que caracteriza a educação em saúde, exigindo o estudo mais cauteloso dos locais onde se encontram pessoas com poder de decisão no que se refere ao sistema de saúde, identificação de lobbies corporativistas, contatos com outros profissionais que não aqueles que em geral se 
encontram nos serviços de atendimento, familiaridade com modelos de atuações provenientes de áreas de conhecimento multidisciplinar e outras formas às vezes muito mais veladas de trabalhar.

Por tudo isso se torna necessário conhecer com mais cuidado os paradigmas que fundamentam as duas principais definições sobre os conceitos de educação e promoção em saúde, apresentados no início deste trabalho. É preciso verificar, também, se as atividades dos especialistas em saúde têm como principal foco o objetivo de provocar mudanças pessoais, justificáveis do ponto de vista das recomendações científicas na área de saúde, o que ocorre em determinados ambientes, já se disse, ou se buscam aqueles objetivos politicamente mais ambiciosos e arriscados, que visam a introduzir mudanças organizacionais/estruturais mais amplas no sistema de saúde.

Talvez seja esse o ponto mais essencial para distinguir a natureza técnico-científica das atividades de cada um. Muitos profissionais tentam atuar concomitantemente em ambas as dimensões - mudança do comportamento individual e mudança do comportamento organizacional para a saúde, porém o custo-benefício de esforços tão diversificados é questionável. Em geral, não podem deixar de limitar suas atuações de acordo com os cargos e funções que desempenham nas agências de saúde ou em outras instituições a elas relacionadas.

O mesmo ocorre no ambiente acadêmico. Os estudos refletem os temas que mais condizem com as preferências pessoais dos pesquisadores, sejam aqueles de natureza educativa ou promocional. Em ambos os casos é preciso definir os conceitos com clareza e fixar os limites do campo de análise, particularmente quando se discutem filosofias de trabalho de interesse para a teoria e para a prática da saúde 
pública, o que nem sempre ocorre em nosso meio. Isso pode levar à divulgação ingênua de atividades sem valor técnico-científico. Mais grave ainda pode levar à aceitação de uma história deformada pelo descuido e pela desinformação que, mesmo quando não se tenha a intenção, acaba por prejudicar a prática e, lamentavelmente, a própria imagem da saúde pública. 
CONSIDERAÇÕES FINAIS 


\section{CONSIDERAÇõES FINAIS}

As discussões na área da educação em saúde têm se prendido geralmente ao nível filosófico, a ponto de esta problemática ter sido denominada na literatura especializada de "falácia filosófica". Quer isto dizer, fala-se muito, mas faz-se pouco. Nesse sentido, tem sido complexa para a educação em saúde a transição dos discursos vazios para abordagens técnicas e aplicações práticas mais coerentes ${ }^{11}$.

Outro ponto negativo para a educação em saúde tem sido a inexistência de documentos oficiais com normas e diretrizes técnicas. Algo que permita a outros profissionais entenderem claramente a prática educativa em nível local. Talvez represente este o ponto mais relevante para futuras atividades destes profissionais.

As organizações profissionais na área de educação em saúde concordam que o desempenho aceitável do educador em saúde depende do apoio concreto que as autoridades administrativas possam lhes dar sob a forma de descrição de seus papeis. É preciso, pois, que estas passem a ter elementos que lhes permitam delineá-los de forma lógica e racional.

\section{Dificuldades}

Segundo Oliveira ${ }^{43}$, percebe-se conflito entre a tendência que emerge da sociedade civil - a saúde como questão social, pautando-se pela construção coletiva do conhecimento, e a definição de saúde como 
questão biológica, ainda fortemente presente na prática sanitária, também na escola, atuando através da transmissão do saber científico.

Percebe-se resistência e insegurança dos profissionais de saúde e dos professores para trabalhar as questões de saúde numa visão integral, transparecendo as questões de poder e a necessidade de se manter o controle social através da norma.

Considerando algumas dificuldades relevantes cita-se (...) uma falta de conhecimentos elementares por parte dos professores na área de saúde e uma quase ignorância (...) das características da criança em idade escolar; (...) inadequação da formação teórica frente às situações práticas com que se defrontam no trabalho (...) [de] transformar-se o pensar no saber-fazer que resulte em uma prática transformadora ${ }^{1}$.

Ao se referir a assuntos de saúde ligados à criança em idade escolar, MYNAYO ${ }^{40}$ se refere aos técnicos do setor saúde (médicos, enfermeiras, assistentes sociais) e professores com uma atuação conseqüente de uma formação que não os orientou sobre (...) os modos de vida, a situação e as causas da pobreza das famílias trabalhadoras. 0 pessoal de saúde não compreende a importância do processo educativo, visto que a maioria recebe ainda treino e experiência em ciências médicas e biológicas, enquanto que o processo educativo tem por base as ciências sociais.

Dando prosseguimento ao raciocínio de OLIVEIRA ${ }^{43}$, poderia-se acrescentar ao arrolamento das dificuldades, autoritarismo na escola, paternalismo, individualismo, imediatismo, voluntarismo e imobilismo, falta de instrumental e recursos, restando à Educação em Saúde ser entendida sob forma de realização de palestras; a educação informal não permeando a assistência; a não-articulação dos programas de 
saúde; insuficientes condições de trabalho; falta de credibilidade nos serviços e em muitos profissionais de saúde; incentivos reduzidos; falta de interesse em se desempenhar o trabalho com competência técnica e compromisso social, devido aos baixos salários; linguagem esotérica, para população, mas própria ao curso médico; redução do conceito de saúde à medicalização, dentre outros.

\section{Desafios}

A operacionalização de propostas como a da Educação em Saúde no contexto da saúde escolar e tendo-se o SUS como política do setor saúde, coloca para o Estado e para a sociedade a exigência do desenvolvimento de novas propostas de coordenação institucional e o desafio de integrar os setores saúde e educação, ampliando-se o conceito e as práticas educativas em saúde 27,28 . Por muito que se fale, que se professe, que se fundamente a prática da Educação em Saúde, não só para crianças em idade escolar, mas nos serviços de saúde e na comunidade, ela ainda está distante de ser alcançada. Enquanto não se possibilitar uma maior aproximação institucional, haverá ações soltas, isoladas, desarticuladas, longe de estarem contribuindo para interesses coletivos.

Têm-se como necessidades sentidas repensar as parcerias, definir com maior clareza os papéis onde a educação possa ir além de divulgar, transmitir, e Educação em Saúde, além de palestras. Tais ingredientes possibilitarão a construção coletiva do conhecimento em saúde, num processo histórico não de curto prazo, mas iniciado a partir 
de uma realidade concreta e se propondo a alcançar metas objetivas e viáveis, porque priorizadas e passíveis de avaliação.

Oliveira ${ }^{43}$, argumenta que:

- Longe de se ter uma visão reducionista destes problemas, pois que aspectos sociais, políticos e econômicos permeiam o processo, mas se objetivando o setor saúde, acredita-se que a menos que governo, profissionais de saúde, da educação e população, se abram ao debate das questões da saúde e da doença; a menos que o conhecimento em saúde seja socializado, a tendência é a manutenção de uma prática tradicional, hegemônica e corporativista, (...) ao invés de um trabalho integrado em equipes, que juntamente com a prática curativa vise a promoção da saúde e a atuação nos determinantes do processo saúde/doença ${ }^{55}$;

- E ainda, a menos que atividades extra-muros, Universidade $\mathrm{x}$ comunidade se dêem em situação de vivência; que se fortaleça o tripé Universidade x serviço x comunidade; que se entenda educação como além de transmitir; que não se entenda saúde como oposto a doença, será a Educação em Saúde concebida como algo além de palestras, as quais estabelecidas legalmente, em 1939, pela portaria 153, venceram a barreira do tempo se fazendo ainda preeminentes nas ações educativas em saúde para escolares.

Não se devem somente aos profissionais de saúde os desencontros históricos do setor saúde, mas deles também se esperam mudanças significativas e urgentes.

A Educação em Saúde pode ser considerada como uma das janelas da escola pela qual o aluno pode melhor compreender o mundo e tornar-se cidadão. 
OLIVEIRA $^{43}$, conclui que se a Educação em Saúde não colocar como sujeito principal do processo o indivíduo/grupo para debater, para analisar criticamente uma dada situação e por si só adotar uma atitude, o processo só mudou de nome. Estará se fazendo Educação em Saúde aos moldes da Educação Sanitária dos dois terços iniciais deste século (século XX).

Se o Estado não se planejar para desenvolver tais ações propostas por documentos oficiais, estará mantendo a prioridade somente à nível de discurso.

Se profissionais de saúde não se identificarem também com ações de atenção primária, estará a população brasileira fadada ao descrédito, ainda existente, dos serviços de saúde pública.

As mudanças sociais, econômicas, políticas e principalmente o fortalecimento dos movimentos populares no Brasil se colocam como estímulo aos profissionais de saúde a repensarem a saúde e a prática educativa nos serviços de saúde e em demais locais considerados espaços para a saúde coletiva, dentre eles, a escola.

Este repensar coloca como prioridade romper com a prática pedagógica que vem se perpetuando. Para tanto, busque-se um referencial teórico que permita orientar as ações/atividades, embasado num conhecimento construído a partir de experiências concretas.

Sem ter a pretensão de resolver os problemas sociais e em particular os problemas da futura escolarização, as instituições planejadas para a educação de crianças de três a seis anos das camadas populares podem colaborar para a melhoria da qualidade de suas vidas, pois sabe-se como o capitalismo é perverso com esta grande 
parte da população. A pré-escola que assiste e guarda a criança, dandolhe alimentação adequada, orientação de higiene e saúde, permitindo que sua mãe trabalhe mais tranqüila, e sem garantir a especificidade potencial dessa instituição, pode estar contribuindo de alguma forma para uma vida melhor; porém, ao pensar que não está educando, corre o risco de educá-la apenas para a ordem e disciplina produzindo apenas a força de trabalho ${ }^{21}$.

COSTA; FUSCELLA ${ }^{16}$, em 1999, afirmam que a importância da educação na existência do ser humano, suas relações com a área da saúde, onde os conhecimentos de ambas as áreas se integram, se interrelacionam e se articulam, é de fato promover transformações na vida das pessoas e conseqüentemente, na realidade de uma sociedade. Levando em consideração esses princípios, observamos que a Educação e a Saúde estão intimamente ligadas ao exercício da cidadania, aos direitos e deveres do cidadão, na luta por melhores condições de vida.

É importante ressaltar que a criança não só será cidadã do futuro, mas já é cidadã hoje ${ }^{48}$.

Os jogos denominados educativos ou didáticos, de acordo com KISHIMOTO ${ }^{34}$, em 1992, conquistam cada vez mais o espaço da educação infantil, pois são considerados essenciais para o desenvolvimento de habilidades de raciocínio e aquisição de conteúdos, afirmando que cada tipo de jogo tem sua peculiaridade e contribui para o desenvolvimento do pré-escolar. Jogos livres favorecem a autonomia, a socialização e jogos didáticos e educativos, iniciam a criança em conhecimentos e favorecem o desenvolvimento de funções mentais. 
Para GARCIA24, uma professora competente dá sentido às atividades, sabendo que cada atividade traz a possibilidade de novas aprendizagens e provoca novos conhecimentos. Coisas simples como lavar as mãos podem tornar-se situações de aprendizagem, não apenas de hábitos, mas de conhecimentos. A professora pode, simplesmente, fazer com que as crianças lavem as mãos antes de comer e depois de ir ao banheiro, freqüentemente elas cantam a música de lavar as mãos, pegam as toalhas e o sabonete, lavam e enxugam as mãos e voltam para sala de aula em fila uma atrás da outra, em silêncio para não atrapalhar as outras aulas. Aprendem com isso apenas a lavar as mãos, mas a professora pode transformar o ritual de lavagem das mãos em "aula de ciências", dizendo que "mão suja traz doenças", mas isso é pouco, uma lupa ajuda ver sujeira, um microscópio ajuda ver os micróbios, que depois de observados podem ser desenhados. Coletivamente e ajudados pela professora, as crianças podem fazer relatórios sobre o assunto e a professora pode trazer livros e revistas para pesquisa dos danos que os micróbios podem causar à saúde. 0 "estudo" pode chegar à questão do saneamento básico e dos direitos da população, dessa forma as crianças estarão adquirindo conhecimentos sobre o mundo, a sociedade e a natureza e sobre si mesmas.

O objetivo da educação pré-escolar é o desenvolvimento global e harmônico da criança. Global, porque inclui os aspectos da pessoa humana, por exemplo, o corpo, a mente, a afetividade, a consciência moral, a integração social. Harmônico, porque todos esses aspectos devem se desenvolver equilibrada e paralelamente, sem exagero de um em detrimento de outro ${ }^{47}$. 
Segundo o manual do agente de saúde escolar ${ }^{5}$, publicado em 1990, partindo do princípio de que, a Educação em Saúde, apesar de suas características específicas, não deve ser desvinculada do processo global de Educação, o professor, por conviver diariamente com o aluno, assume um papel fundamental, pois pode ajudar na descoberta de sintomas que indicam problemas de saúde, não percebidos pela família e nem mesmo pelo próprio aluno. A partir do momento em que as mães tiveram que trabalhar fora de casa, para ajudar na renda familiar, muitos dos cuidados com a saúde e a educação da criança foram delegados ao professor, tornando-o um elemento fundamental no processo ensino-aprendizagem, fazendo que com a escola exerça sua função socializadora, formando cidadãos conscientes de seus direitos, dentre os quais, a saúde.

0 resultado deste estudo demonstra que os documentos estudados oferecem importante fonte de pesquisa para alunos e profissionais, da Saúde ou Educação, interessados na educação em saúde, especialmente na educação em saúde bucal voltada às instituições de educação infantil. 0 resultado esperado será altamente positivo se os programas educacionais forem desenvolvidos em conjunto e contando com a integração e envolvimento de membros da comunidade, das universidades e equipes das áreas da saúde e educação, enfatizando a integração das atividades de Educação em Saúde à Educação em Saúde Bucal, em função do desenvolvimento integral da criança e de seu direito legal e moral à Educação e Saúde, garantidos na Constituição Nacional. 


\section{BIOÉTICA}

“Devemos, portanto, buscar uma visão globalizante, uma visão totalizante de nosso 'paciente'. Isto demanda um desafio: vencer a tendência natural de olhar a realidade dentro da ótica específica de nossa área odontológica; reduzir o paciente aos seus dentes" 49 .

\section{ÉTICA PROFISSIONAL}

“A Odontologia é uma profissão se que exerce, em benefício da saúde do ser humano e da coletividade, sem discriminação de qualquer forma ou pretexto"13. 
REFERÊNCIAS BIBLIOGRÁFICAS 


\section{REFERÊNCIAS BIBLIOGRÁFICAS*}

1 AMORIM, O.F. de Educação para a saúde no Brasil - o caso do Distrito Federal. Belo Horizonte, 1989. 165p. Dissertação (Mestrado) - Escola de Veterinária, Universidade Federal de Minas Gerais apud OLIVEIRA, M.L. de, Concepções, dificuldades e desafios nas ações educativas em saúde para escolares no Brasil. Divulg. Saúde Debate, n.18, p.43-50, jun. 1997.

BONOW, M.L.M.; CASALLI, J.de F. Avaliação de um programa de promoção de saúde bucal para crianças. J. bras. Odontoped Odonto Bebe. v. 5, n. 27, p. 390-94, set./out. 2002.BRASIL, Constituição (1988). Constituição da República Federativa do Brasil. DF, Senado, 1988.

BRASIL, Constituição (1988). Constituição da República Federativa do Brasil. DF, Senado, 1988.

BRASIL, Lei n.10.172, de 9 de janeiro de 2001. Disponível na Internet: http://www.pedagogiaemfoco.pro.br/110172 01.htm em 21/01/2004. Estudante. Manual do agente de saúde escolar. 2.ed. Brasília, 1990. Fundamental. Referencial curricular nacional para a educação infantil. Brasília, MEC/SEF, 1998. Introdução, v.1.

\footnotetext{
*Normas recomendadas para uso no âmbito da Universidade de São Paulo, com base no documento "Orientações básicas para apresentação de dissertações e teses na FOBUSP", publicado pelo Serviço de Biblioteca e Documentação da Faculdade de Odontologia de Bauru - Universidade de São Paulo, 1991.
} 
BRASIL, MINISTÉRIO DA EDUCAÇÃO E DO DESPORTO. Secretaria de Educação Fundamental. Referencial curricular nacional para a educação infantil. Brasília, MEC/SEF, 1998. Formação pessoal e social, v.2.

BRASIL, MINISTÉRIO DA EDUCAÇÃO E DO DESPORTO. Secretaria de Educação Fundamental. Referencial curricular nacional para a educação infantil. Brasília, MEC/SEF, 1998. Conhecimento de mundo, v.3.

CANDEIAS, N.M.F. Conceitos de educação e de promoção em saúde: mudanças individuais e mudanças organizacionais. Rev. Saúde públ., v.31, n.2, p.209-13, abr. 1997.

CANDEIAS, N.M.F. Forças propulsoras e restritivas na área de educação em saúde pública. In: Ação participativa: perspectivas de atuação dos educadores de saúde pública. Brasília, Divisão Nacional de Educação em Saúde, 1984, p.19-49 apud OLIVEIRA, M.L. de, Concepções, dificuldades e desafios nas ações educativas em saúde para escolares no Brasil. Divulg. Saúde Debate, n.18, p.43-50, jun. 1997.

11 CANDEIAS, N.M.F.; ABUJAMRA, A.M.D. ; PEREIRA, I.M.T.B. Delineamento do papel profissional dos especialistas em educação em saúde - uma proposta técnica. Rev. Saúde públ., v.25, n.4, p.289-98, ago. 1991.

12 CANHOLATO, M.C. et al. Diagnóstico da pré-escola no Estado de São Paulo. São Paulo, Fundação para o Desenvolvimento da Educação, 1990. 
15 CLEARY, H.P. Health education: the role and functions of the specialist and the generalist. Rev. Saúde públ., v.22, n.1, p.64-72, fev. 1988.

16 COSTA, I. do C.C.; FUSCELLA, M.A.P. Educação e saúde: a importância da integração dessas práticas na simplicidade do saber. Ação Coletiva, v.2, n.3, p.45-7, jul./set. 1999.

17 CURY, C.R.J. A educação infantil como direito. In: Subsídios para credenciamento e funcionamento de instituições de educação infantil. Brasília, MEC/SED/DPEF, 1998. p.9-16.

18 DELDINE, R.; VERMEULEN, S. O desenvolvimento psicológico da criança. Bauru, EDUSC, 1999

19 DEWEY, J. Schools of tomorrow. 15.ed. New York, Dutton \& Company, 1924 apud VIDAL, D.G.; HILSDORF, M.L.S. Brasil 500 anos: tópicas em história da educação. São Paulo, Edusp, 2001.

20 DONNANGELO, M.C. Saúde e sociedade. São Paulo, Cortez, 1976 apud OLIVEIRA, M.L. de, Concepções, dificuldades e desafios nas ações educativas em saúde para escolares no Brasil. Divulg. Saúde Debate, n.18, p.43-50, jun. 1997.

21 FARIA, A.L.G. de. Educação pré-escolar e cultura. 2ed. Campinas, Cortez, 2002. 239p.

22 FREUD, S. Cinco lições de psicanálise; A história do movimento psicanalítico; 0 futuro de uma ilusão; 0 mal-estar na civilização; Esboço de psicanálise. Seleção de textos Jayme Salomão. São Paulo, Abril Cultural, 1978 apud KLATCHOIAN, D.A. Psicologia odonto pediátrica. 2.ed. São Paulo, Ed. Santos, 2002. 
23 FROEBEL, F. The education of man. New York, Ed. W. T. Harris, 1912 apud KISHIMOTO, T.M. Educação infantil integrando pré-escola e creches na busca da socialização da criança. In: VIDAL, D.G.; HILSDORF, M.L.S. Brasil 500 anos: tópicas em história da educação. São Paulo, Edusp, 2001. Cap.10, p.225-40.

24 GARCIA, R.L. Discutindo a escola pública de educação infantil - a reorientação curricular. In: PEREZ, C.L.V. et al. Revisitando a pré-escola. 5ed. São Paulo, Cortez, 2001. p.11-20.

25 GREEN, L.W. Polices for decentralization and development of health education. Rev. Saúde públ., v.22, n.3, p.217-20, jun. 1988.

26 GREEN, L.W.; KREUTER, M.W. Health promotion planning, an educational and environmental approach. 2.ed. Mountain View, Mayfield Publishing Company, 1991 apud CANDEIAS, N.M.F. Conceitos de educação e de promoção em saúde: mudanças individuais e mudanças organizacionais. Rev. Saúde públ., v.31, n.2, p.209-13, abr. 1997.

27 HILGERT, E.C. Educação em saúde bucal no ensino fundamental em escolas de Porto Alegre. Porto Alegre, 2001. 163p. Dissertação (Mestrado) - Faculdade de Odontologia de Porto Alegre, Universidade do Rio Grande do Sul.

28 HILGERT, E.C.; ABEGG, C. Suportes teóricos para educação em saúde bucal nas escolas: uma abordagem qualitativa. Rev. Fac. Odont. Porto Alegre, v.43, n.2, p.65-71, dez. 2002.

29 InSTITUTO NACIONAL DE ESTUDOS E PESQUISA EDUCACIONAIS. Sinopse estatística da educação básica: Censo escolar, 2002. Disponível na Internet: http://www.inep.gov.Br/básica/censo/Escolar/Sinopse/sinopse 2002.htm. 
em 6/04/2003.

30 KISHIMOTO, T.M. Educação infantil integrando pré-escola e creches na busca da socialização da criança. In: VIDAL, D.G.; HILSDORF, M.L.S. Brasil 500 anos: tópicas em história da educação. São Paulo, Edusp, 2001. Cap.10, p.225-40.

31 KISHIMOTO, T.M. A pré-escola em São Paulo (das origens a 1940). São Paulo, Loyola, 1988.

32 KISHIMOTO, T.M. Escolarização e brincadeira na educação infantil. In: SOUZA, C.P. de. História da Educação. São Paulo, Escrituras, 1998. p.123-38.

33 KISHIMOTO, T.M. Froebel e a concepção de jogo infantil. Rev. Fac. Educ. Univ. São Paulo, v.1, n.1, p.145-68, jan./jun. 1996.

34 KISHIMOTO, T.M. O jogo, a criança e a educação. São Paulo, 1992. 255p. Tese (Livredocência) - Faculdade de Educação, Universidade de São Paulo.

35 KLATCHOIAN, D.A. História da infância. In: Psicologia odonto pediátrica. 2.ed. São Paulo, Ed. Santos, 2002. Cap.6, p.53-8.

36 KNUTSON, J.W. What is public health. In: Pelton, W.J.; WISAN, J.M. Dentistry in public health. 2.ed. Philadelphia, Saunders, 1955. p.1-10 apud CHAVES, M.M. Odontologia Social. 3.ed. São Paulo, Artes Médicas, 1986.

37 LEAVELL, H.R.; CLARK, E.G. Preventive medicine for the doctor in his community. An epidemiological approach. New York, McGraw Hill, 1958 apud CHAVES, M.M. Odontologia Social. 3.ed. São Paulo, Artes Médicas, 1986.

38 LEIS de DIRETRIZES e BASES da EDUCAÇÃO INFANTIL. Disponível na Internet: 
hppt://www.mec.gov.br/leges/pdf/LDB.pdf em 12/03/2003.

39 McGAVRAN, E.G. What is public health. In: School of public health. The practice of dental public health. Michigan, Ann Arbor, 1956. p.5-12 apud CHAVES, M.M. Odontologia Social. 3.ed. São Paulo, Artes Médicas, 1986.

40 MINAYO, M.C. de S. A saúde em estado de choque. São Paulo, Espaço e Tempo, 1986 apud OLIVEIRA, M.L. de, Concepções, dificuldades e desafios nas ações educativas em saúde para escolares no Brasil. Divulg. Saúde Debate, n.18, p.43-50, jun. 1997.

41 MINISTÉRIO DA SAÚDE. Ministério da Criança. Estatuto da criança e do adolescente. Brasília, Imprensa Nacional, 1991.

42 NUNES, R.A.da C. História da educação no século XVII. São Paulo, Editora da Universidade de São Paulo, 1981.

43 OLIVEIRA, M.L. de, Concepções, dificuldades e desafios nas ações educativas em saúde para escolares no Brasil. Divulg. Saúde Debate, n.18, p.43-50, jun. 1997.

44 OLIVEIRA, M.L.C.L. de. Educação em saúde na escola pública: limites e possibilidades uma reflexão histórica sobre a forma do educador. Rio de Janeiro, 1991. Dissertação (Mestrado) - Instituto de Estudos Avançados em Educação, Fundação Getúlio Vargas apud OLIVEIRA, M.L. de, Concepções, dificuldades e desafios nas ações educativas em saúde para escolares no Brasil. Divulg. Saúde Debate, n.18, p.43-50, jun. 1997.

45 PARÂMETROS CURRICULARES NACIONAIS. Disponível na Internet: http://www.zinder.com.br/legislação/pcn-inf.htm em 23/03/2003. 
46 PINAZZA, M.A. Recursos didáticos na pré-escola: um estudo baseado em depoimentos de professores. São Paulo, 1989. Dissertação (Mestrado) - Instituto de Psicologia, Universidade de São Paulo.

47 PREFEITURA MUNICIPAL DE BAURU. Secretaria Municipal de Educação. Proposta curricular para as escolas municipais de educação infantil. 1987. Bauru, Art-graff, 291p.

48 PREFEITURA MUNICIPAL DE BAURU. Secretaria Municipal de Educação. Proposta pedagógica de educação infantil do município de Bauru. 1996. Bauru, Gráfica São João, 179p.

49 RAMOS, D.L. de P. A bioética e a obtenção do consentimento para intervenções odontopediátricas. In: KLATCHOIAN, D.A. Psicologia odonto pediátrica. 2.ed. São Paulo, Ed. Santos, 2002. Cap.3, p.29-35.

50 RICE, M.; CANDEIAS, N.M.F. Pradrões mínimos da prática da educação em saúde - um projeto pioneiro. Rev. Saúde públ., v.23, n.4, p.347-53, ago. 1989.

51 RICHARDSON, B.W. The health of nations. A review of the works of Edwin Chadwick. London, Longmans, 1887 apud CHAVES, M.M. Odontologia Social. 3.ed. São Paulo, Artes Médicas, 1986.

52 RIZZO, G. Educação pré-escolar. 3.ed. Rio de Janeiro, Livraria Francisco Alves Editora S.A., 1985.

53 SHATTUCK, L. et al. Report of the Sanitary Comission of Massachusetts, 1850. Cambrige, Harvard University Press, 1948 apud CHAVES, M.M. Odontologia Social. 3.ed. São Paulo, Artes Médicas, 1986. 
54 SILVA, M.A. Síntese dos Referenciais curriculares nacionais para a educação infantil. Disponível na Internet: http://www.pr.gov.br/def/edinf/referenc.pdf em 16/03/03.

55 TEIXEIRA, S.M.F. Antecedentes da reforma sanitária - textos de apoio. Rio de Janeiro, Escola Nacional de Saúde Pública, 1988 apud OLIVEIRA, M.L. de, Concepções, dificuldades e desafios nas ações educativas em saúde para escolares no Brasil. Divulg. Saúde Debate, n.18, p.43-50, jun. 1997.

56 VIDAL, D.G.; HILSDORF, M.L.S. Brasil 500 anos: tópicas em história da educação. São Paulo, Edusp, 2001.

57 WALTER, L.R. de F.; FERELLE, A.; ISSAO, M. Odontologia para o bebê. São Paulo, Artes Médicas, 1996, 246p. 
ABSTRACT 


\section{ABSTRACT}

\section{SMALL CHILDREN AT SCHOOLS OR PUBLIC INSTITUTIONS OF INFANTILE EDUCATION AND THE BUCCAL HEALTH EDUCATION}

The objective of this study was to identify, to describe and to interpret historical aspects, conceptual and legal, the difficulties and challenges that relate the small child and the infantile education, emphasizing the buccal health education in the institutions of infantile education. It was analyzed official documents and others related with education and/or health that it serves or it will serve as a support to the actions of buccal health education developed in the institutions of infantile education. The primordial objective was to supply theoretical supports for professionals and students of the Health and Education areas that participate, develop or intend to participate and/or to develop educational programs about buccal health to children with tender age. The result of this study affirms that the studied documents offer important research source for students and professionals of the Health or Education area, interested in Health Education especially in Buccal Health Education to infantile education institutions. The expected result will be highly positive if the education programs could be developed together with integration and involvement of the community's members, the universities and teams of the health and education areas, emphasizing the integration to the activities of Health Education to the Buccal Education Health, in function of the children's integral development and their legal and moral rights of having education and health ensured by National Constitution. 